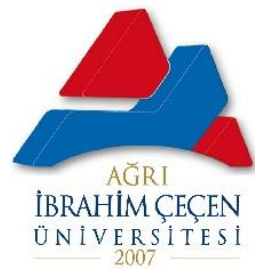

\title{
Z Kuşağı ve Öğretmenlik Mesleği
}

Generation $\mathrm{Z}$ and Teaching Profession

\section{Arş. Gör. Ahmet KARADOĞAN}

Atatürk Üniversitesi Kâzım Karabekir Eğitim Fakültesi Türk Dili ve Edebiyatı Eğitimi ahmet.karadogan@atauni.edu.tr

iD https://orcid.org/0000-0002-7183-3929

Ağrı ibrahim Çeçen Üniversitesi Sosyal Bilimler Enstitüsü Dergisi-Journal of Ağrı ibrahim Çeçen University Social Sciences Institute AiCUSBED 5/2 Ekim/Oktober 2019 / Ağrı

ISSN: $\quad 2149-3006$

e-ISSN: 2149-4053

\begin{tabular}{|l|l|}
\hline Makale Türü-Article Types : & Araştırma Makalesi \\
\hline Geliş Tarihi-Received Date $:$ & $\mathbf{2 7 . 0 7 . 2 0 1 9}$ \\
\hline Kabul Tarihi-Accepted Date $:$ & $\mathbf{2 4 . 0 8 . 2 0 1 9}$ \\
\hline Sayfa-Pages $:$ 9-42 & doi https://doi.org/10.31463/aicusbed.597636 \\
\hline
\end{tabular}

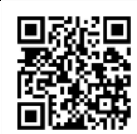

http://dergipark.gov.tr/aicusbed

This article was checked by

$\checkmark$ iThenticate 

AĞRI IBRAHIM ÇEÇEN ÜNIVERSiTESi

SOSYAL BiliMLER ENSTiTÜSÜ DERGisi

Journal of Ağm ibrahim Çeçen University Social Sciences Institute AiCUSBED 5/2, 2019, 9-42

\section{Z KUŞAĞI VE ÖĞRETMENLİK MESLEĞİ}

Generation $\mathrm{Z}$ and Teaching Profession

$$
\text { Arş. Gör. Ahmet Karadoğan }
$$

\section{Özet}

Gerçek yaşamda kazanılan başarıların eğitimle edinilmiş becerilerle doğru orantılı olduğu söylenebilirken günümüzde de bireylerin eğitim ve öğretiminin büyük çoğunluğunun okullar yoluyla kazandırıldığı savunulabilir. Öğretimin baş aktörlerinden biri olan öğretmenlerin bu konudaki katkıları nesillerin şekillenmesinde büyük rol oynamaktadır bu sebeple öğretmenlerin nesillerin genel özelliklerinin ve etkilendikleri durumların farkında olmaları öğretimi planlayabilmeleri açısından önemlidir. Nesil Teorisi ve bunun etkileriyle belirlenen nesil özelliklerini dikkate alarak eğitimi ve öğretimi planlamak öğretmenlere yardımcı olacaktır. Kuşak kelimesi, yaklaşık aynı yıllarda doğan, benzer koşulları yaşayan, dolayısıyla benzer problemleri ve kaderleri paylaşan, benzer görevleri yapmak zorunda kalan bir grup insan olarak adlandırılabilir. Kuşak sıralamasında da en güncel kuşaklardan biri Z Kuşağı' dır. Genel olarak literatür tarandığında Z Kuşağı'nın 1995-2005 yılları arasında doğmuş bir topluluğu kapsamakta olduğu görülmektedir. Ayrıntılı olarak ele alınacak olan Z Kuşağı'nın en belirgin özelliği dijital yerliler, ekran gençliği gibi kavramlarla tanımlanmış olmalarıdır. Bu çalışma Z Kuşağı'nın genel özelliklerini ve öğrenme durumlarını ortaya koymayı amaçlayıp öğretmenlere yol göstermesi için yapılmış literatür taramasına dayalı bir derleme çalışmasıdır. Çalışmada Z Kuşağı'nın belirlenen özellikleri ile hangi durumlarda daha iyi öğrenme çıktılarına ulaşılabileceği konusundaki fikirler ortaya konulmuştur.

Anahtar Kelimeler: Öğretmenlik, eğitim, Z Kuşağı, dijital yerliler, ekrangençliği.

\section{Abstract \\ It can be said that the success accomplished in daily life are directly proportional to the skills which are acquired through education. Nowadays, it}

http://dergipark.gov.tr/aicusbed 5/2 Ekim / Oktober 2019 
10|A rş. Gör. A hmet Karadoğa n

can be argued that most of the individuals' education and training are gained by schools. Teachers' contribution to this subject which is one of the main actors of teaching plays a big role in shaping the generations. For this reason, it is important for teachers to know the general characteristics of generations and the situations in which they are affected so that they can plan teaching program. Planning the education and training by considering the production characteristics determined by the Generational Theory will help the teachers. The word generation can be called a group of people born in about the same years, living in similar conditions, sharing similar problems and destinies, and having to perform similar tasks. One of the most recent generations in the generation is Z Generation. In generally, when the literature is examined, it is seen that Generation $\mathrm{Z}$ includes a community born between the years of 19952005. The most prominent feature of Generation Z, which will be discussed in detail, is that it is defined by concepts such as digital natives and screenagers. This study aims to reveal the general characteristics and learning situations of the $\mathrm{Z}$ generation. This review study is based on a literature review for guiding to teachers. By the current study, $\mathrm{Z}$ generations determined characteristics and situations in which the learning outcomes can be achieved are presented.

Key Wors: Teaching, education, Generation Z, digital natives, screenagers.

\section{Giriş}

Öğrenme öğretme ortamının en önemli değişkenlerinden biri (Sönmez, 2008: 148) belki de eğitim sisteminin en temel ögesi (Eskicumalı, 2002: 9) öğretmendir. İnsanlık tarihi boyunca öğretmenlik, toplumsal değerlerin gelecek kuşaklara aktarıcısı ve bilgi ile bilgiye talepte bulunanlar arasında bir köprü olduğu için en saygın meslekler arasında yer almıştır (MEB, 2017). Eskicumalı (2002) öğretim etkinliklerini formel eğitim kurumlarında yürüten uzman kişileri öğretmen olarak tanımlamaktadır. Millet olarak güç ve değer kazanabilme, sağlıklı bir toplumsal örgütlenme gerçekleştirebilme, bilginin belirli amaçlar çerçevesinde etkin olarak öğretilmesiyle sağlanabilmektedir. $\mathrm{Bu}$ durum eğitim ve öğretmen kavramlarını toplum için hayati bir hâle getirmektedir (MEB, 2017). Bir ülkenin kalkınmasında, nitelikli insan gücünün yetiştirilmesinde, toplumdaki huzur ve sosyal barışın sağlanmasında, bireylerin sosyalleştirilmesi ve toplumsal hayata hazırlanmasında, toplumun kültürünün ve değerlerinin genç kuşaklara aktarılmasında, öğretmenler başrolü oynamaktadır. Öğretmenler toplumların gerçek mimarları ve insan kişiliğini şekillendiren sanatkârlardır

http://dergipark.gov.tr/aicusbed 5/2 Ekim / Oktober 2019 
(Eskicumal1, 2002: 9). Eğitim sistemlerinin bu temel işlevleri etkin olarak yerine getirebilmesi, sistem içerisindeki öğretmenlerin niteliğine bağlıdır. $\mathrm{Bu}$ nedenle bir ülkede eğitimle ilgili çıktıları iyileştirmenin yolu, öncelikle öğretmen niteliklerini geliştirmekten geçmektedir. Öğretmenler eğitimin başlatıcısı, geliştiricisi ve uygulayıcısı olarak eğitim sisteminin en hayati ögesi olduğundan, nitelikli öğretmen yetiştirme çabası ve kaygısı her zaman toplumların gündeminde önemli bir yer tutmuştur (MEB, 2017). Öğretmenlik diğer öğreten kişi/gruplardan farklı olarak uzmanlık gerektirir. Çünkü öğretmen olmak öğreten olmaktan oldukça farklıdır. Öğretenin düzenlediği yaşantılar gelişigüzeldir. Öğretmen ise belli bir program çerçevesinde planlı ve programlı eğitim öğretim yaşantıları düzenleyerek öğrencilerde istenilen davranış değişikliklerini meydana getirmeye çalışır (Eskicumalı, 2002: 8). İstenilen davranış değişiklerini meydana getirmek için de öncelikli koşul öğrencilerin tanınmasıdır. Günümüz toplumunda öğrenci profilinin değişmesi durumu sebebiyle öğrencilerin tanınması daha da önemli hâle gelmiştir. Nesillerin yetişme koşulları, etkilendikleri durumlar vb. hem öğrenme stillerini hem de etkili öğretmenin nasıl sağlanabileceği konusu üzerinde etkilidir. Bu sebeple dönemlere göre öğretmenlik mesleğinin güncellenmesini ve öğretmenin zamanın koşullarına uyum sağlayarak öğretimini planlamasını gerekli kılar.

\section{Çalışmanın Amacı}

$\mathrm{Bu}$ çalışmanın amacını günümüzün popüler kavramlarından olan kuşak kavramına ve bu bağlamda $\mathrm{Z}$ Kuşağı olarak adlandırılan topluluğun öğrenme durumları ve özelliklerine 1şı tutarak öğretmenlere yol göstermek olarak belirlemek mümkündür. Çalışma değişen öğrenci profili ve öğrenme durumlarının gözler önüne serilmesi ve çeşitli fikirler sunarak öğretmenlere yol gösterici nitelikte olması açısından önemli görülmektedir. Yapılan çalışmanın tüm eksikleri ve hataları ile daha kapsamlı ve daha anlamlı çalışmalara önayak olması amaçlanmaktadır.

\section{Çalışmanın Yöntemi}

$\mathrm{Bu}$ çalışma literatür taramasına dayalı bir derleme çalışması olarak düşünülmüştür. Çalışmada yöntem olarak doküman analizi yöntemi kullanılmış olup literatür taraması sonucunda elde edilen kaynaklar derlenip analiz edilerek bazı sonuçlara varılmış ve bu sonuçların öğretmenlere fayda sağlayacağı düşünülen yönleri eleştirel olarak ele alınarak bazı öneriler sunulup çalışma sonlandırılmıştır. 
$12 \mid$ A rş. Gör. A h m e t $K$ a rado ğa $n$

\section{Kuşak Kavramı ve Z Kuşağı}

Genel olarak belirli yıllar arasında doğan kişiler kuşak ya da nesil olarak ifade edilmektedir. Kuşak kelimesi TDK sözlüğünde "Aşağı yukarı aynı yıllarda doğmuş olup aynı çağın koşullarını, dolayısıyla birbirine benzer sıkıntıları, yazgıları yaşamış, benzer ödevlerle yükümlü olmuş kişilerin topluluğu" olarak ifade edilmektedir. Tarih felsefesinde ve kültür tarihinde ise "Yeni bir anlayışta yeni bir yaşama duygusunda, yeni biçimlerde birleşen, eskiden belirgin çizgilerle ayrılan kişilerin topluluğu" olarak tanımlanmaktadır Medeni Hukuk Terimleri Sözlüğü’nde ise "nesil “ olarak ifade edilmektedir. Marshall (1999: 439)'a göre ise;

Bir kuşak, bir toplumun yaklaşık olarak aynı zamanlarda doğan üyelerinden oluşan yaş gruplarının bir biçimidir. Son yillarda, yaş gruplarının toplumsal değişime katkılarını inceleyen kuşak analizlerine duyulan ilgi sürekli artmaktadır. Örneğin Karl Mannheim bir denemesinde (The Problem of Generations, 1952), ayn kuşaktan insanların, kendilerinden önceki kuşaklara göre dünyaya nasıl çok farklı biçimlerde bakabileceklerini anlatır. Dolayısılla, her kuşağa özgü olan eşsiz deneyimler toplumsal değişime olanak tanir. Glenn H. Elder Children of the Great Depression (1974) adl çalışmasında, tutumluluğun egemen olduğu bir çağda yetişen kuşakların, ekonomik refah dönemlerinde büyüyen çocuklara klyasla çok farklı dünya görüşleri olduğunu gözler önüne sermiştir. Kuşak terimi, bir nesil ile öteki arasında geçen dönem için de kullanılır. Birbiri peşi sıra gelen kuşakların toplumsallaşmasındaki farklılıklarla ilgili araştırmalarda, kuşaklar arası çatışma her şeyi kapsayan bir tema olarak kalmakla birlikte, hem değerlerde hem davranışlardaki sürekliliğin veya süreksizliğin ölçüsü konusunda bir anlaşmaya varılmış değildir. Her kuşak içinde, gerçeklikle ilgili birbiriyle çatışan ve kusmen cinsiyet, etnik köken ve toplumsal sinıf gibi başka özelliklerden kaynaklanan görüşler olabilir. Üzerinde durulması gereken başka bir nokta kuşak kimliklerinin kalıcılığıdır. Örneğin, gençliklerinde protesto hareketlerine katılanlar orta yaşlara geldiklerinde nasıl tutumlar benimserler? Anlaşılacă̆ı üzere, yaşam seyriyle ve yaşlanmayla ilgili araştırmalar kuşaklara duyulan ilgiyle yakından bağlıdır.

\footnotetext{
${ }^{1}$ http://sozluk.gov.tr/ adresinden 30.07.2019 tarihinde erişilmiştir.
} 
Reeves \& Oh (2008) iş yerinde, kolejlerde, üniversitelerde ve diğer bağlamlarda göz önünde bulundurulması gereken kuşaksal farklılıkların var olup olmadığı konusunda az bir fikir birliği olduğunu ifade ederken, Swanzen (2018) ise her nesilde, gençlik profilinin değişmesi ile birlikte, ebeveynliğin ve toplum katılımının niteliğinin de değiştiğini belirtir. Okullarda ve üniversitelerde öğretim, öğrenci ve öğretmen arasındaki kuşak farkının az olduğu görüşü yavaş yavaş yerini ne kadar büyüdüğü görüşüne bırakmaktadır. Gençlerin nasıl öğrendiği, gelecekteki firsatları ve refahı ile ayrılmaz bir şekilde bağlantılıdır. Bu nedenle, her kuşak için kim oldukları, etraflarındaki dünyayı nasıl işledikleri, otorite ile nasıl ilişki kurduğu, bunun aileyi ve toplumu nasıl etkilediği ve etkileme olasılığını göz önünde bulundurmak belirlenen hedeflere ulaşmak için önemlidir (Swanzen, 2018). Çeşitli kuşakları etiketlemek için standartlaştırılmış herhangi bir terminoloji kullanılmamaktadır. Ayrıca, nesillerdeki tanımların belirsiz olması ve yazarların kesin tarihler konusunda aynı fikirde olmamaları da dikkat çekicidir. Kesin tarihlerinde birlik gösteremeyen yazarlara ek olarak, birçok yazar, bireylerin ve toplumun karmaşık doğası göz önüne alındığında, bireyleri bir bütün olarak kuşaklara bölmenin haklılığını sorgulamaktadır (Bump, 2015). Fakülte ve öğrencilerin kuşak çeşitliliği, önemli öğretme ve öğrenme düşüncelerini ortaya çıkarır çünkü kuşak çeşitliliği sadece yaş farklı1ıklarından daha fazlasını ifade eder. Nesiller hakkındaki literatür bize her neslin kendine has bir değer, fikir, etik ve kültür dizisi olduğunu söyler. $\mathrm{Bu}$ nesiller arasındaki farklılıkları anlamak, fakülte öğrencilerinin öğrenme ihtiyaçlarını daha iyi karşılamak için çeşitli öğretim stratejileri kullanmasına yardımcı olabilir. Buna ek olarak fakülte, tüm öğrencilerde öğrenmeyi en iyi hâle getirmek için kendi ön yargılarını ve farklı kuşakların anlayışlarını incelemelidir (Johnson \& Romanello, 2005: 212) . Bugünün yükseköğretim kurumlarında kayıtlı çeşitli öğrenci nesillerinin yanı sıra kurumsal iş yerinde çalışan farklı nesillerin eğitim ve öğretimi için farklı bir yaklaşım gerektirdiği belirtilmektedir. Ayrıca eğitim tasarımcıları ögretimi geliştirirken nesiller arası farkl11ıkları göz önünde bulundurmalı ve bu nesiller arasındaki farklılıkların, eğitim teknolojisinin çeşitli uygulamalarının farklı etkililiğini incelemek üzere tasarlanan araştırmalar için anlamlı bir değişken (Desai \& Lele, 2017) olmasını göz ardı etmemelidir.

Farklı danışmanlar ve araştırmacılar, nesiller arasındaki farklılıkları yazarken ve araştırırken, belirli nesiller etiketleyen farklı isimler bulmuşlardır (Reeves \& Oh, 2008). Wiedmer (2015) Z Kuşağı'nı, en yeni nesil olarak tanımlar ve birkaç on yıl içinde dünyaya öncülük edeceğini ifade eder. " $Z$

http://dergipark.gov.tr/aicusbed 5/2 Ekim / Oktober 2019 
Kuşağı", "Generation V" (sanal için), "Generation C/ C Kuşağı" (topluluk veya içerik için), "Generation Cox/Kaptan Kuşak", "The New Silent Generation/Yeni Sessiz Kuşak", "Internet Generation/İnternet Kuşağı", "Google Generation/Google Kuşağı", "Yerli Kuşak", "The Sharing Generation/Paylaşma(Paylaşan) Kuşağı(Kuşak)", "All Technology All the Time/ Hep Teknolojik Kuşak", "Born Digital/Digital Doğanlar", "Gen Z", "Facebook Üretimi", "Dijital Yerliler" veya bazen "iGeneration" dâhil olmak üzere bu popülasyon grubuna atıfta bulunmak için farklı araştırmacılar tarafindan bir çok kavram kullanılmıştır (Igel ve Urquhart, 2012; Schroer, 2008; Seemiller \& Grace, 2016; Tari, 2011; Turner, 2015; Twenge, 2017; Wiedmer, 2015). İnternetten önceki bir zamanı hatırlamamaları sebebiyle Marc Prensky'nin popülerleştirdiği bir terim olan "dijital yerliler/digital natives" kavramıla isimlendirilmişlerdir. Ayrıca teknolojik bağlantıları bu nesle "dijital yerliler" adını kazandırmıştır (Horovitz, 2012). Z Kuşağ internetsiz bir zaman tanımamış bu da onları gerçek dijital yerliler hâline getirmiş̧ir (Chicca ve Shellenbarger, 2018; Igel ve Urquhart, 2012; Loveland, 2017; Rickes, 2016; Seemiller \& Grace, 2016; Shatto ve Erwin, 2016, 2017; Spears vd., 2015; Turner, 2015; Twenge, 2017; Wiedmer, 2015). Prensky, diğerlerinin yanı sıra, dijital teknolojinin her yerde varlığının, gençlerin bilgiyi işleme ve etkileşime girme şeklini değiştirdiğine inanmaktadır. Değişiklikler o kadar yaygın ki $\mathrm{Z}$ Kuşağı için başka bir adlandırma da "ekrangençliği/screenagers" ${ }^{2}$ dir. Bu nesil hakkında -şimdilik- fazla bilgimiz olmamasına rağmen, Z Kuşağı'nın büyüdüğü ve yetiştiği çevre hakkında çok şey bilindiği söylenebilir.

Kuşaksal farklar - özellikle Baby Boom Kuşağı, X Kuşağı ve Milenyum (Y) Kuşağı olarak farklı şekilde tanımlanan kuşaklar arasındaki farklar - popüler basında ve bilimsel yayınlarda sıkça tartışılmaktadır (Reeves \& Oh, 2008). Öte yandan Y Kuşağı, X Kuşağı'nı takip eden bireylerin oluşturduğu gruptur. Milenyum Kuşağı olarak da adlandırılırlar. Kesin bir tarih yoktur ancak kaynaklar genellikle bunları 1981-1995 arasında doğmuş olanlar olarak ifade eder. Finansal kararlar alırken çevrim içi ya da mobil (yazılı mesajlaşma) ve yüz yüze iletişimi tercih etmektedirler. Y Kuşağı

\footnotetext{
${ }^{2}$ Ekrangençliği. Kişisel bilgisayar, oyun konsolu, tablet ve akı1lı telefon ekranı önünde vakit geçiren; bilgisayar, akıllı telefon, tablet, sosyal medya ve internet kullanmada usta olan ve bunlarla büyüyen, ekranlar dünyasına meraklı genç olarak tanımlanmaktadır. Şunu da ifade etmek gerekir ki televizyon bu ekranlar arasında artık en eski olanıdır ve ekrangençliğinin yeni bir televizyon izleme anlayışı vardır. İstediğim zaman izlerim, program çeşidi ve saatini ben seçerim vb.
} 
teknolojiye açık bir tutkuyla sahiptir. Kullanmaktan hoşlanırlar ve bireysel olarak değil, ekip ortamlarında öğrenmeyi tercih ederler (Childs, Gingrich \& Piller, 2009; Coates, 2007; Dulin, 2005; Robertson Associates, 2013; Shih \& Allen, 2007). Bu birey grubu her zaman çok özel muamele gördü ve ebeveynleri tarafından korunma altına alındılar. Bu kuşak motive olmuş, hedef odaklı, geleceğe yöneliktir ve ekip odaklı olarak ele alınmıştır (Howe \& Strauss, 2003). Bununla birlikte, internetin yaygınlaşması ve kullanıma başlanmasının 1990 sonrası olduğu düşünülürse Y Kuşağı'nın internet dünyasında doğduğu söylenemez. Dijital yerliler olarak tanımlamak da yanlış olacaktır kanaatindeyiz. Bu kuşağın belirli ürünlerinin de tablet ve akıllı telefonlar olması internetin bu kuşağın sonlarına doğru yaygınlaşması sebebiyle çok mümkün görünmemektedir. Ancak tercih ettikleri iletişim yolu SMS ve E-mail olarak görülebilir. Sosyal medyayla da oldukça sonradan tanışmışlardır. Ancak bu kuşağın genel olarak çıkan son teknoloji ürünlere rağbet etmeleri, teknolojiye tutkuyla bağlı olmalarına ve kuşağın kapsadığı yılların sonuna doğru teknoloji ile tanışmış olmalarına bağlanabilir.

Z Kuşağı ise Y Kuşağı'nı takip eden, 1995 yılında veya sonrasında doğan (Bassiouni \& Hackley, 2014) yeni bir topluluğu temsil eder ve tarihteki en küresel ve sosyal olarak güçlenmiş (Desai \& Lele, 2017) Batı ya da birinci dünya kültürlerinde yaşayan insanların kuşağı olarak görülmektedir. Hemen önceki kuşağı olan Milenyum/Y Kuşağı ile bazı benzerliklere sahip olan Z Kuşağ bazı önemli farklılıklara da sahiptir. Her nesil, grubun kendine özgü özelliklerine ve gereksinimlerine katkıda bulunan geçerli ekonomik, sosyal ve kültürel koşullardan etkilenir (Rickes, 2016; Seemiller \& Grace, 2016). Z Kuşağı, teknoloji ve dijital cihazların patlamasından, ekonomik dengesizlikten ve güvenlik güvencesizliğinden etkilenen belirsizlik ve değişim zamanlarında büyümüştür (Rickes, 2016; Seemiller \& Grace, 2016; Turner, 2015; Twenge, 2017; Wiedmer, 2015). Ayrıca, şüpheli ve pragmatik ebeveynler tarafindan da büyütülmüş olmaları da ihtiyatlı bir neslin ortaya çıkmasına yol açmıştır denebilir (Rickes, 2016; Seemiller \& Grace, 2016; Shatto \& Erwin, 2016, 2017; Twenge, 2017; Wiedmer, 2015).

Şenbir (2004) 2003 ve sonrası doğumlu bireyleri Z Kuşağı olarak ifade etmektedir. Ancak genel olarak literatüre bakıldığında 2003'ün geç bir tarih olduğu kanısı ön plana çıkmaktadır. Genel literatürde başlangıç tarihi olarak 1990/1995 ile bitiş tarihlerinin 2010/2015 olarak ön plana çıktığı görülmektedir. Dahası nesillerin hangi yıllara yayılacağı konusunda yazarlar arasında hâlâ büyük bir anlaşmazlık vardır (Desai \& Lele, 2017). Z Kuşă̆ı'nın en eski üyeleri doğduğunda, 1990'dan 2001'e kadar değişen, ancak çoğunluk 
1996 ile ilgili iddialarda bulunulduğu için tarihler farkl1lık gösterir. Desai \& Lele (2017)'nin Howe \& Strauss (2000), Lancaster \& Stillman (2002), Martin \& Tulgan (2002), Oblinger \& Oblinger (2005), Tapscott (1998), Zemke vd. (2000)'den yaptığ tabloya göre; Mature Generation 1925-1945, Boom Generation 1946-1964, X Kuşağ1 1965-1980, Milenyum/Y Kuşağı 19811989, Z Kuşağı ise 1990'dan günümüze olarak ifade edilmiştir. Kuşaklar aras1 ortalama 15 ya da 20 y1llık bir süreç geçmesi gerektiği kabul edilirse bu ifadenin Milenyum Kuşağı'nı yanlış tanımladığı sonucuna varılabilir. Z Kuşağı 1995'ten 2012'ye kadar doğanları içerir (Andrea, Gabriella \& Timea, 2016; Seemiller \& Grace, 2016; Shatto \& Erwin, 2016; Turner, 2015; Twenge, 2017). Bununla birlikte, yazarlar $Z$ Kuşağı tarihlerinde kesin olarak aynı fikirde değillerdir. Bu konudaki literatür ortaya çıkmaya devam ettikçe kesin tarihler düzeltilebilir. Schroer (2008), Z Kuşağı üyelerinin 1995-2015 doğumlu olduğunu ve şu anda hızla büyüyen bir nüfusa sahip olduğunu belirtir. Z kuşağının başlangıcı 1995, World Wide Web'in hâlka açık hâle geldiği yaklaşık zamanla aynı zaman denk gelmektedir (Chicca \& Shellenbarger, 2018; Igel \& Urquhart, 2012; Loveland, 2017; Rickes, 2016; Seemiller \& Grace, 2016; Shatto \& Erwin, 2016, 2017; Spears vd., 2015; Turner, 2015; Twenge, 2017; Wiedmer, 2015). Swanzen (2018)' in Isacosta, (уyy.); Matthews, 2008; Shafrir, 2011; Howe, 2014; Stankorb \& Oelbaum, 2014; Sterbenz, 2015; Jenkins, 2017; ve Zeigenhorn, 2017'dan uyarladığı tabloya göre Z Kuşağı 1994-2012 yıllarını kapsamakla birlikte bu kuşak iki bölüme ayrılmıştır. Bunlardan ilki 1994 ve 2007 yılları arsındaki topluluğu kapsamaktadır. Bu topluluk 2020 Kuşağı, Postmilenyum Kuşağı, iGeneration olarak isimlendirilmiştir. Bu kuşağın ilk bölümü olan topluluk Dotcom Balonu (Dot com bubble ${ }^{3}$ ), dijital küreselleşme (digital globalization) ve siber zorbalığa maruz kalmıştır. Bu kuşağın ikinci topluluğu ise Centennials (Asırlıklar), Vatan Kuşağı, Yeni Sessiz Kuşak olarak isimlendirilmiştir. Azalan doğum ve üreme oranları, milliyetçiliğe doğru hareket, büyük durgunluk, fiziksel hareketsizlik ve online zaman kavramları da bu topluluğun önemli olayları olarak ifade edilmiştir. Kanımızca Z Kuşağı'nın "Dijital Yerliler" ve "Teknolojik Doğanlar" ya da "Ekrangençliği" olabilmesi için gerekli olan ilk şart internetin yaygınlaşması olarak görülebilir. Bu da 19901995 yıllarına denk gelmektedir. Bu sebeple bu kuşağın tarihsel olarak

\footnotetext{
${ }^{3}$ Dotcom Balonu (Dotcom Bubble), 90'lı y1lların sonunda internetin ve teknoloji endüstrisinin yükselişiyle ortaya çıktı ve 2000'li yıllarda bir "borsa balonu" olarak tarihe geçti. Ayrıntılı bilgi için bakınız: https://konupara.com/yatirim/borsa/dotcombalonu-12896/ 01.05.2019 tarihinde erişilmiştir.
} 
belirlenmesinde 1995 yılının başlangıç olarak alınması daha uygun görülmektedir. Yenidoğanın interneti hemen kullanamayacağı da bu bilgilere eklenirse ve çalışmanın amaçlarına göre, 1995-2015 yılları arasını Z Kuşağı'nın zaman çizelgesi olarak belirlemek daha anlamlı olacaktır. Ayrıca Renfro (2012), Z Kuşağı için tam başlama ve durma noktalarının kuşak etiketlerinde belirsiz olduğunu, isim veya kesin doğum tarihi aralığı üzerinde bir anlaşmaya varılmadığını söylemektedir. Kuşakların bitiş yıllarında çakıştı̆̆ı da unutulmamalıdır. Bir neslin bittiğini ve diğerinin ne zaman başladığını belirten kesin belirteçler veya yol işaretleri yoktur (Zemke, Raines \& Filipczak, 1999).

Kuşak isimlendirmelerinin farklılaşması ve dönem olarak farklı yılları kapsaması, genel olarak bir sonraki kuşağın bir önceki kuşak tarafından eğitilmesi ve kuşaklar arası geçişin bu sebeple daha yumuşak olması ile açıklanabilir. Bunun yanında kesin bir kuşak ayrımı yapılmasında ara kuşaklar doğacak ve bu kuşakların da isimlendirilmesi gerekecektir. Ayrıca bir kuşağın başlangıç tarihi olarak alınan yıl ile sonlandığı yıl arasında da farklılıklar olacağı bir başka değişken olarak karşımıza çıkmaktadır. Başka bir deyişle, o kişinin kronolojik nesiller içindeki herhangi bir topluluğa üyeliğini temel alan varsayımlar yapmak kesinlikle haksızlıktır (Desai \& Lele, 2017). Ancak Z Kuşağ1, McCrindle (2010)'a göre demografik olarak önceki her kuşağa göre farklıdır. Kuşakların özellikleri farklıdır ancak Z Kuşağı, teknoloji ile gerçekten büyüyen ilk nesildir ve belki de daha rahat olmaları, dijitalleşmeye yatkın olmaları beklenebilir. Belirlenen özelliklerin ortalamalara dayandığını belirtmek de önemli görülmektedir. Başka bir deyişle, Z Kuşă̆ı'nın tüm üyeleri bu genellemelerle benzer özellikler göstermeyebilir (Philip \& Garcia, 2013; Seemiller \& Grace, 2016; Twenge, 2017).

\section{Z Kuşağının Özellikleri}

Z Kuşağ 1 şimdiye kadarki kuşaklar arasında ilk en küresel, en teknolojik, okuma yazma ve sosyal olarak güçlenmiş kuşak olarak ifade edilebilir. Buradaki sosyallik doğrudan ilişkiler yerine daha çok sosyal medyadaki aktiflik ve bağlantı çeşitliliği olarak düşünülebilir. Neredeyse doğuştan teknoloji ile şekillenirler. Olağanüstü bir şekilde teknolojiye bağımlıdırlar ve ana dilleri teknolojik bir dildir (Reeves \& Oh, 2008). Bu onların iletişimine de yansitılabilir. Hızlı hareket eden, sürekli değişen bir toplumda büyüdüklerinden, hıza doğruluktan daha fazla değer verir, çok görevli ve çoklu kaynaklardan gelen bilgileri özümserler (McCrindle, 2006 ve Grail Research, 2010'dan akt. Desai \& Lele, 2017). Daha önceki nesiller ile karşılaştırıldığında, dijital medyaya daha fazla maruz kalmaları nedeniyle

http://dergipark.gov.tr/aicusbed 5/2 Ekim / Oktober 2019 
daha iyi bir ağa sahip, daha fazla çeşitlilik arz eden, çeşitliliğe daha toleranslı ve çevrim içi sosyal ağlarda kayda değer zaman harcadıklarından bahsedilebilir (Grail Research, 2010 akt. Desai \& Lele, 2017). Dijital yerli nesil sürekli olarak birbirine bağlıdır (Palfrey \& Gasser, 2008). İletişim yolları, elde taşınan (ya da giysilere entegre edilmiş) iletişim aygıtlarıdır. İletişim kurarken yüz yüze iletişimi -FaceTime, Twitter ve Snapchat gibitercih etmektedirler. Satın alma veya finansal karar çözümleri, başka kaynaklar araştırmaktan ziyade, "arkadaş" ve "takipçi" listelerine talepte bulunma veya sorular sormadır, bu kuşak dijital olarak kalabalıklaşacaktır (Robertson Associates, 2013). Z Kuşağ1, ayrıca küresel, sosyal olarak bağlantılı, görsel ve teknolojik bir kuşak olarak görülmektedir. Bu, önceki Milenyum/Y Kuşağı tarafından şekillendirilen, ancak şimdi teknoloji ve sosyal medyayı önceki topluluktan farklı bir şekilde şekillendiren yeni sosyal medya sınıfıdır. Ancak, belki de, bu neslin insanları arasında daha da yeni bir gelişme olarak, herkesin okuması ve görmesi için Facebook ve Twitter'da hayatlarını geniş çapta ve halka açık yayınlamak yerine Snapchat vb. gibi sosyal platformlar daha popülerdir. Belki de uygun şekilde gelişim hızına bakıldığında ve bu neslin yeniliğe olan düşkünlüğü sayesinde, Facebook ve Twitter giderek daha "eski" olmaya başlayacak, onlara "eski" bir iletişim biçimi olan e-posta da katılacaktır. Facebook, Skype, Facetime vb. sayesinde Z Kuşağı aynı fiziksel alanı işgal etmeyen bireylerle "gerçek" bir şekilde iletişim kurmaktadır. Aile ve arkadaşlarla bu tür bir iletişim ülke genelinde veya dünyada gerçekleşebilir ve sürekli güncellemeler, metinler ve görsel bağlantılar, etkileşimler ile gerçek zamanlı diyalog içerebilir. Bununla birlikte, bu bağlanabilirlik çoğu kişiyi karakterize edebilir. Y Kuşağı ile karşılaştırıldığında, Z Kuşağı'nın mücadele kavramının farkında olmadığı söylenebilir. Pratik, bilge değil zeki ve cesur oldukları için önderlik etmeyi sevdiklerinden bahsedilebilir. Seleflerinden daha sabırsız ve daha çeviktirler, sürekli olarak yeni zorluklar ve dürtüler ararlar (Tari, 2011).

Z Kuşağı tüketicileri, eski kuşaklardan farklı davranırlar ve bu durum tüketici davranışlarında değişikliklere yol açabilir (Schlossberg, 2016). Puiu (2016), Z Kuşağı'nın farklı tüketici tercihleri, fikirleri, davranışları ve önceki nesillere sosyal konularla ilgili farklı kararlar verdiğini; bu nedenle karakteristik Z Kuşağı düşüncesini, tercihlerini ve kararlarını belirlemeyi esas olarak görür.

Z Kuşağ1 McCrindle (2010)'a göre daha büyük annelerde doğmuş, daha küçük ailelerde yaşamakta ve çağlara göre en az kardeşe sahip kuşaktır. Kadın başına düşen toplam doğum sayısının ikinin altına düştüğü bir çağda

http://dergipark.gov.tr/aicusbed 5/2 Ekim/ Oktober 2019 
doğmuşlardır. Okula her zamankinden daha genç yaşta başlamış, tarihte en formel olarak eğitilmiş nesildir ve eğitimde her zamankinden daha uzun süre kalmaları öngörülmektedir (Desai \& Lele, 2017). Z Kuşağı yüzeysel ve bölünmüş dikkatle karakterize edilebilir, çünkü aynı anda daha fazla medya aracını kullanırlar. Akıllı, dikkat çekici ve pratikler. Görsel bir çağda dünyaya geldiklerinden, trendlerde değil sahnelerde düşünürler (Reeves \& Oh, 2008). Kültürel içeriklere serbest girebilme ve bunlardaki renklilik onların zevkini hızlı bir şekilde oluşturmaktadır. Çevre koruma ve bilgi değerleri onlar için önemlidir (Tari, 2010'dan akt. Desai \& Lele, 2017).

Z Kuşağ1 üyeleri internetin her zaman var olduğu bir dönemde büyüdüklerinden dolayı bilgiye ulaşmak onlar için bir "tık" uzaktadır. Sadece birkaç parmak hareketiyle istedikleri bilgilerin büyük bir bölümüne ulaşabilir ve kullanabilirler. Dijital medya ile sürekli etkileşim hâlinde olduklarından hız ve erişilebilirlik onlar için oldukça önemlidir. İnternetsiz bir ortamda bulunmak onlar için oldukça sıkıcıdır. Alışkın oldukları sosyal mecralardan uzak kalmanın yoksunluk belirtilerine neden olabileceği söylenebilir. Z Kuşağı üzerindeki belirleyici etkilerden biri, dijital teknolojinin doygun olduğu ve mobil cihazların aracılık ettiği bir dünyada büyüyüp yaşlanmalarıdır. Birçoğu, cep telefonlarından ayrıldıklarında "nomofobi" yaşadıklarını, kaygı hissi yaşadıklarını itiraf etmektedir. Ancak bugün, hepimiz önemli bir şey yapıyormuş gibi telefonlarımıza bakıyoruz. Çocuklar olarak, Z Kuşağı buna yol açan mükemmel bir gerçeklik firtınası yaşadı: Onlar her zaman yetişkinler tarafından korunuyor ve denetleniyorlardı. Taşınabilir cihazlar her yerde kullanılabilir hâle geldi ve daha kolay etkileşim sağladı. Zihinsel sağlık sorunları artıyordu ve kendilerini bunalmış hissediyorlardı. Telefonlarıyla daha yalnızdılar, bu da sosyal becerilerin atrofiye uğramasına neden oldu (Elmore, 2019b).

Facebook hesabına sahip gençlerin yüzde 94'ü tarafından belirtildiği gibi (2012 itibarıyla), Z Kuşağı sosyal medyada oldukça etkindir (Lenhart, 2013). Fakat Z Kuşağı'nın büyük bölümünün Snapchat, Whisper ve Secret gibi sosyal ağları tercih ederken, 13 ila 17 yaşları arasındaki kuşak üyelerinin 2017'de Facebook'tan ayrıldığ 1 ve en çok kullanılan web sitesinin YouTube olduğu tahmin ediliyor (Valdeavilla, 2017'den akt. Swanzen, 2018). Bu kuşak videolarını ve bağlantılarını çevrim içi olarak paylaşarak bilgileri toplar ve yayar (Relander, 2014). Z Kuşağı'nın, akıllı telefonlarda, tabletlerde ve dizüstü bilgisayarlarda dijital ortam kullanılması nedeniyle gün boyunca birkaç ekran arasında ileri ve geri geçiş (Relander, 2014) yaptığı söylenebilir. Sosyal medya ve dijital reklam, Z Kuşă̆ı'nın günlük teknoloji ve internet

http://dergipark.gov.tr/aicusbed 5/2 Ekim / Oktober 2019 
20|A rş. Gör. A hmet Karadŏgan

kullanımıla ilgili olarak verilen önemli pazarlama stratejileridir (Glum, 2015). İnternetin, Z Kuşağı'nın gelişiminin çekirdeğini oluşturduğu ve internet bu kuşağın dünya görüşlerine, zihinsel sağlıklarına, günlük programlarına, uyku düzenlerine, ilişkilerine ve daha pek çok şeye benzersiz bir şekilde etki ettiği söylenebilir. Cihazlar neredeyse sürekli olarak kişi üzerinde bulunmakta ya da zihinlerinde yer almaktadır. Z Kuşağı'nın dünya görüşünün (ve buna bağlı olarak ahlaki kurallarının) oldukça kapsayıcı ve bireysel olduğundan bahsedilebilir. $\mathrm{Bu}$ farkl1, açık görüşlü genç grup, başkalarının duygu ve deneyimlerine karşı duyarlıdır. Herhangi bir görüşün doğru veya yanlış olduğunu iddia etmekten sakınmakla birlikte hedefleri, mesleki başarı ve finansal güvenlik çevresinde şekillenmekte ve çoğunluk, nihai hedeflerinin "mutlu olmak" olduğunu söylemektedir ki bunu da, çoğulculuk ve finansal başarı olarak tanımlanabilmektedir. Z Kuşağı, insanların farklı inanç ve deneyimlere sahip olabileceğinin farkındadır ve sosyal kapsayıcılığ görünmektedir. Z Kuşağı normları, önceki kuşağın normlarından farklıdır. Z Kuşağı tarafindan kullanılan kelimeler, sözcükler ve ifadeler ebeveynleri için oldukça tuhaf ve iki taraf için de birbirinden ayrılmaktadır. Z Kuşağı teknoloji dünyasında doğduğundan ve bu dünyada kendilerini iyi hissettiğinden, bu çevrelerle çevrelenmeleri öncelikli olarak önemlidir (takipçi, beğeni vb.). Herhangi bir teknik cihazda, neredeyse durmadan, her zaman çevrim içidirler. Yaptıkları eylemlerle görülebilmek isterler. Diğer sosyalleşme biçimleri onlar için çok zor olarak görülmektedir (Tari, 2011). 20. ve 21. yüzyılın nesilleri arasında zaten belirgin olan iki fark, Y Kuşağı ve Z Kuşağı'nın eski üyelerinin kendilerini anlamlı bir şekilde topluma dâhil etmeleri ve çeşitliliği kabul etmelerinin gerekliliğidir.

Çoğunlukla $\mathrm{X}$ ve $\mathrm{Y}$ kuşakları ebeveynlerinin yavruları olarak, $\mathrm{Z}$ Kuşağı'nın birçoğunun ailesi ile karmaşık bir dinamik yapıya sahip olduğu görülmektedir. Z Kuşağı'nın, dijital teknolojiyle doygun olan ve mobil cihazların aracılık ettiği bir dünyada yaşlanacağı da söylenebilir.

Mutte (2004) Z Kuşağı üyelerinin, iş yerini sevmemeleri durumunda, önceki nesillere göre daha hızlı bir ritim içinde yaşadıklarından ani değişime hazır olacaklarını belirtir. İş yerlerini değiştirmelerinin doğal olacağını ve tek bir yerde sıkışıp kalmak istemediklerini, ödün vermeden ayrılacaklarını söylemektedir. Elmore (2019a) Z Kuşağı'nı zorlayan bir dünya olmasından ötürü daha açık fikirli olduklarını ve daha farklı bakış açılarına sahip olduklarını belirtir. Ayrıca önceki nesillere göre daha uzun süre eğitim ortamında bulunmalarında ötürü iş gücüne katılımlarında daha az deneyimli

http://dergipark.gov.tr/aicusbed 5/2 Ekim / Oktober 2019 
olacakları da ifade edilebilir. Çünkü Z Kuşağı yarı zamanlı bir işte çalışmak yerine daha çok ev ödevleri ile ilgilenmektedir. Bunun yanında dersten arta kalan zamanlarda da farklı faaliyetlerle meşgul olmaktadırlar. Bu sebeple tecrübesizdirler ve 20'li ya da 30'lu yaşlarda iş hayatına başladıklarında da hayati bir yaşam becerisini kaçırmış olacaklardır. İş gücüne girdiklerinde sosyalleşmeyi zor bulmakta, iş yerinde yaşlı nesiller ile birlikte olmaya ve sorumluluk almaya kolayca uyum sağlayamamaktadırlar. Bu gençler bağl1lık ve formaliteden hoşlanmamaktadır. Z Kuşağı, dürtüyü uyaran daha alt bilişsel bölgeler, kısa mesajlar, Facebook vb. güncellemeleri ve video oyunları tarafından sağlanan nörolojik uyarılmanın bombardımanı ile sürekli harekete geçmektedir. Aynı zamanda, sözde Google öğrenme kültürü - saniyeler içinde herhangi bir soruya cevap bulma - Z Kuşağı gençliğinin konsantre olma, yazma ve yansıtma şeklini değiştirmeye devam etmektedir. Doğrusal düşünme kapasiteleri, bilgi hızları, ayrık ve örtüşen şekilde alıp vermeleri gereken yeni bir düşünme modu ile değiştirilmektedir. Tóth-Bordásné \& Bencsik (2011) Z Kuşağı'nın bilgi paylaşımını şöyle ifade eder; Sanal düzeyde, kolay ve hızlı bir şekilde ve halka açı olarak yapılmaktadır. Takım çalışmasını ise sanal düzeyde (sadece zorunluysa) (Bencsik \& Machova, 2016: 46) yaptıkları ifade edilmektedir. Birçok ebeveyn ve öğretmen, Snapchat, Netflix, Facebook, Twitter ve internetin geri kalanının yalnızca bir tık ötede olması sebebiyle, çocuklarının ya da öğrencilerinin nasıl konsantre olabileceğini merak etmektedir. 7 gün 24 saat çevrim içi dünyaya bağlanabilmenin büyük oranda baştan çıarmaya sebep olduğu söylenebilir. Elbette cezalandırılma internet bağlantısının kesilmesi kadar kolaydır. Bazı öğrenciler ya da çocuklar için bu çevirim içi olabilme durumu, daha yavaş kitap okumaya ve belki de daha az kitap okumaya veya derste verilen materyallerin amacına ulaşamamasına yol açabilir. Bununla birlikte kullanıcı, çevrim içi bilgiye daha kolay ulaşabilir. Ders kitaplarını her zaman yanlarında bulundurmanın esnekliğini ise dezavantajdan daha avantajlı bulabilir.

Z Kuşağı'nın yaşamı boyunca maruz kaldığı teknolojinin kaçınılmaz etkisi olarak, dijital dünyanın hevesli tüketicilerinin bu dünyanın bilgi birikimi, iletişimi ve etkileşiminde teknolojiye güvenmeye yol açtığ söylenebilir (Igel \& Urquhart, 2012; Loveland, 2017; Rickes, 2016; Seemiller \& Grace, 2016; Shatto \& Erwin, 2016, 2017; Spears vd., 2015; Turner, 2015; Twenge, 2017; Wiedmer, 2015; Chicca \& Shellenbarger, 2018). Bu grup, neredeyse sadece dijital telefonlara bağlanıyor ve günde birkaç saatini akıllı telefonlarına harcıyor (Shatto \& Erwin, 2016, 2017). Sonuç olarak, bu kuşak az gelişmiş sosyal ve ilişki becerilerini ortaya koymakta, onları tecrit, kaygı,

http://dergipark.gov.tr/aicusbed 5/2 Ekim / Oktober 2019 
güvensizlik, depresyon ve diğer zihinsel sağlık endişeleri riskine sokmaktadır (Igel \& Urquhart, 2012; Seemiller \& Grace, 2016; Spears vd., 2015; Twenge, 2017; Wiedmer, 2015). Z Kuşağ1 üyeleri, sosyal medyadaki akranlarıyla, yetersizlik duygularını ağırlaştırabilecekleri sürekli karşılaştırmalar yapmaktadır (Twenge, 2017). Z Kuşağ 1 telefon vb. çevrim içi ortamlar sebebiyle en yalnız kuşak olarak ifade edilmektedir. Bağlı oldukları sosyal mecralarda arkadaş sayıları her ne kadar çok olsa da bunlar sanal olduğundan dolayı ya da göstermelik yapıldığından dolayı depresyona girme ve sosyalleşme becerilerinin daha zayıf olabileceği söylenebilir. Ek olarak, bu nesil teknolojiden sürekli uyarılmaya alışkındır (Loveland, 2017; Seemiller \& Grace, 2016; Shatto \& Erwin, 2016, 2017; Twenge, 2017; Wiedmer, 2015). Sanal bir dünya $\mathrm{Y}$ ve $\mathrm{Z}$ için doğaldır, ancak birçoğu çevrim içi yaşamlarını çevrim dışı yaşamlarına sığdıramaz. Gerçeklik ile arzular arasında bir miktar boşluk olduğunu düşünemezler ve varlığın belirsizliğini hissetmektedirler. Endişeli, hayal kırıklığına uğramışlar, evde oturuyorlar ve birilerinin onlara dikkat etmesini ve ebeveynleri tarafından sıkça söylenenlere geri bildirim vermelerini bekliyorlar: harikalar (Tari, 2011). Sürekli değişimlerden korkmazlar ve internet dünyası nedeniyle çok fazla -bir dereceye kadarbilgiye sahiptirler. Problemleri çözmek için internette çözümler bulmaya çalışırlar (Tari, 2011).

Z Kuşağ1 duygusal, fiziksel ve finansal istikrarsızlık zamanlarında büyüdü (Rickes, 2016; Seemiller \& Grace, 2016; Turner, 2015; Twenge, 2017; Wiedmer, 2015). Kamusal şiddet ve ekonomik belirsizlik, önceki nesillere göre daha az duygusal, fiziksel ve finansal risk alma olasılığı yüksek olan pragmatik, ihtiyatlı ve endişeli bireylere yol açmıştır (Loveland, 2017; Rickes, 2016; Seemiller \& Grace, 2016; Shatto ve Erwin, 2016, 2017; Turner, 2015; Twenge, 2017; Wiedmer, 2015). Bu ihtiyatlı doğa bir nesil hareketsiz eylemciye yol açtı (Twenge, 2017; Wiedmer, 2015). Başka bir deyişle, Z Kuşağı, aktif olarak katılımla ilgili bir olayla ilgili sosyal medyada bir mesaj göndermeyi tercih eder. Olumlu olarak, Z Kuşağı, farklılıklardan memnun olan açık fikirli ve çeşitli bir popülasyonu temsil etmektedir (Loveland, 2017; Seemiller \& Grace, 2016; Shatto \& Erwin, 2016, 2017; Turner, 2015; Twenge, 2017; Wiedmer, 2015). Ayrışma zamanları olmadan büyüdüklerinden dolayı 1rkçıllı̆ı̆n neden hâlâ var olduğunu anlamakta güçlük çekmektiler (Twenge, 2017).

Shatto ve Erwin (2016), Z Kuşağ1 öğrencilerinin diğer tüm jenerasyonlardan daha fazlasının gözlemle ve pratik yaparak okuma ve dinleme yoluyla öğrendiklerini belirtmiştir. Çevrim içi kaynaklardan bilgi

http://dergipark.gov.tr/aicusbed 5/2 Ekim / Oktober 2019 
edinme yetenekleri etkileyici görünmekle birlikte ancak bilginin geçerliliğini eleştirme yeteneğine sahip değiller ve eğer cevaplar hemen belli olmazsa büyük olasılıkla hayal kırıklığına uğrayacaklar. $\mathrm{Bu}$ nedenle, öğrencinin dikkatini çekmek ve daha üst düzey düşünme becerilerini geliştirmek, başarılı öğretimin kritik bileşenleridir. Ayrıca çevrim içi olarak geçirecekleri zaman nedeniyle Yeni Sessiz Kuşak olarak adlandırılsalar da, Z Kuşağı'nın, diğer kuşaklardan daha yaratıcı olduğunu söylemek mümkündür.

Burada ifade edilmesi gereken önemli bir nokta da bu kuşağın henüz sınıfları doldurmasından dolayı geleceğe yönelik ifadelerin kesinliğinin sorgulanabilir oluşudur. Yani bu nesli tanımlayacak özelliklerin çoğu henüz ortaya çıkmamıştır. Fakat bazı çalışmalarda bu kuşağa ait bazı genel özellikler belirlenmiştir.

Tabscott'a (2009: 6) göre, bu neslin sekiz özel özelliği veya normu vardır. Bunlar iş birliği, özgürlük, inceleme, kişiselleştirme, eğlence, dürüstlük, hız ve yeniliktir. Özgürlük ve seçim özgürlüğü bu kuşak için önemlidir. Bir şeyleri özelleştirmek, kendilerini yapmak istemektedirler. Konuşmadan hoşlanmakla birlikte derslerden hoşlanmazlar. Doğal iş birlikçidirler. Bütünlük konusunda 1srar etmekte ve titizlik göstermektedirler. Okulda ve hatta işte eğlenmek istemelerinin yanı sıra hız ve yenilikçilik hayatlarının bir parçasıdır ve onlar için normaldir.

Z Kuşağı'nı tanımlayan altı karakteristiği Elmore (2019c) ise şu şekilde belirtir;

1. Alaycıdırlar. Öğrenciler oldukça mutlu olmasının yanı sıra idealist değil zorlu ekonomiden, terörizmden ve yaşamın karmaşıklıklarından bıkmış durumdayken bile daha gerçekçi olma eğilimindedirler.

2. Özeldirler. Snapchat ve Whisper gibi uygulamalar, son birkaç yllda patlayıcı bir büyüme kaydetti. Buna karşıllk, Facebook bu demografinin yüzde 25'ini 2011'den bu yana kaybetti. Kendi kuşaklarından önce olanları değil kendi kuşaklarına uygun olanı kullanma eğilimindedirler.

3. Onlar Milenyum Kuşağı gibi girişimcilerdir. Bu öğrenciler sadece bir kariyere yerleşen olmayı değil, öncü olmayı planlıyorlar. Mevcut lise ögrencilerinin \%72'si bir işe başlamak istiyor. Hayatın zor olduğunu ve iş gerektirdiğini biliyorlar.

4. Çok görevliler. Milenyum Kuşağı gibi 2 ekranda değil, aynı anda 5 ekranda olmayı tercih ediyorlar. Gözlerine değil etraflarına bakarken onlarla iletişim kurmaya hazır olunmalıdır.

5. Hiper farkındalar. Z Kuşağı, deneyimlediklerini ortaya çıkarmak için pazarlama araştırmacıları ve akademisyenler ile yeterince iletişime geçmiştir.

http://dergipark.gov.tr/aicusbed 5/2 Ekim / Oktober 2019 
24|Arş. Gör. A hmet Karadŏg a n

4D düşünme ile zihinleri pek çok yöne doğru aktığından, çevrelerine aşırı duyarlılığı olan postmodernler hâline geldiler.

6. Teknolojiye bağımlılar. Bu sizi şaşırtmaz. Milenyum Kuşağı'nın teknolojiye bağımlı olduğunu düşünürsek daha fazlası için hazır olunmalıdır. Anketlerde, bu gençler teknolojiyi hava ve su ile aynı kategoriye koyuyorlar. Her zaman bağlantıda olmadan yaşamayı hayal edemezler. Sonuç olarak bu çocuklar için hazır mısınız?

Öte yandan, geleneksel aile yapısından farklı aile yapılarına sahip olmak ve farklı kültürel bakış açılarına maruz kalmak, Z Kuşağı'nı farklılıkları kabullenip açık fikirli kılmaktadır.

Mevcut literatürde tanımlanan dokuz $\mathrm{Z}$ Kuşağı niteliği şöyle sıralanabilir; Yüksek teknoloji tüketicileri ve dijital dünyanın özü olan, dijital dünyanın özlemcileri, bireysel, az gelişmiş sosyal ve ilişki becerilerine sahip, izole, anksiyete, güvensizlik ve depresyon gibi ruh sağlığı sorunları için artan risk altında olan, dikkat süresinin eksikliği, kolaylık ve çabukluk isteyen, pragmatik, temkinli ve duygusal, fiziksel ve finansal güvenlik ile ilgili, yerleşik aktist, hareketsiz eylemci, açı fikirli, farklı ve farklılıklara karşı rahat ve çeşitli olan (Igel \& Urquhart, 2012; Loveland, 2017; Rickes, 2016; Seemiller \& Grace, 2016; Shatto \& Erwin, 2016, 2017; Spears vd., 2015; Turner, 2015; Twenge, 2017; Wiedmer, 2015).

Bütün sıralanan bu özelliklerin yanı sıra Lolarga (2016) Z Kuşağı'nın özelliklerini; doğuştan 5 ekranla öğrendiğini, 4 boyutlu düşündüğünü, pragmatik ve ihtiyatlı olduğunu, akıllıca paylaşan, aktif gönüllüler olduğunu, harmanlanmış olduklarını (ırk ve cinsiyet bakımından), olgun olduklarını, görüntülerle iletişim kurduklarını, bir şeyler yapma odaklı olduklarını, alçak gönüllü olduklarını, gelecek odaklı, realist, başarı için çalışmak isteyen, ortak vicdana sahip olduklarını belirtmiştir.

Z Kuşağı'nın üyeleri motivasyonda hızlı ücret, özgürlük, taahhüt kavramlarını önemsediği; performans değerlendirmede kendi sınırlarını tanımayan, öz güven sahibi, değerler ve öz imajı bozabilen; eğitim, öğrenme, gelişmede ilgi temelli ve enformel öğrenmeye yatkın; çatışma yönetiminde ise çatışmaları kışkırtan ancak takip etmeyen ya da agresif tepki veren (Andrea, Gabriella \& Tímea, 2016) bireyler olarak ifade edilmiştir.

\section{Dijital Çağda Öğretmenlik Mesleği}

Dünyadaki toplumsal, ekonomik, siyasal, finansal ve teknolojik değişimler öğretmenlik mesleğinin değişim ve gelişimi yakından takip etmesi gerekliliğini doğurmuştur. Özellikle kitle iletişim araçları, her geçen gün bilgiye ulaşma yollarını daha da artırmakta ve çeşitlendirmektedir. $\mathrm{Bu}$

http://dergipark.gov.tr/aicusbed 5/2 Ekim / Oktober 2019 
yüzyılın öğrencisi kullandığı bilgi kaynağının öğretmen tarafından da kullanılmasını beklemekle birlikte bu kullanımı kendince de gerekli gördüğü ifade edilebilir. Bu sebeple sadece Düz Anlatım Yöntemi’yle ders işlemeye çalışan öğretmen baştan yenilmiş sayılabilir. Öğretmen, öğrenci motivasyonunu sağlamak için bu güçlü kaynak ve bilgileri daha cazip hâle getirip motivasyonu artırmak için kullanabilir (Eacute \& Esteve, 2000'den akt. Yaşaroğlu, 2018). Bu kapsamda yaşanan değişimler öğretmenleri bireysel olarak etkilerken öğrenci profillerinde farklılaşmaya sebep olmaktadır. $\mathrm{Bu}$ farklılaşmalar belirli yıllar arasında doğan öğrencilerin benzer profillere sahip olacağına anlamına gelmektedir. Kuşak çeşitliliğini anlamak, eğitimcilerin öğrenci öğrenmelerini en üst düzeye çıkarmasına olanak tanır çünkü eğitimciler ve öğrenciler birbirlerinin kişisel geçmişlerini, özelliklerini ve öğrenme gereksinimlerini değerlendirmektedir. Hagevik ( akt. Johnson \& Romanello, 2005: 216) şöyle ifade etmektedir: "Çocukken edindiğiniz inançlar riskleri ve zorlukları, otoriteyi, teknolojiyi, ilişkileri ve ekonomiyi, terfi ettiğiniz durumları etkiler". Çocukluğun kişisel ve toplumsal etkileri kabul edildiğinde, hem öğrenci hem de öğretmen kendilerinin ve başkalarının çevrelerindeki dünyayı nasıl etkilediklerini daha iyi anlayacaktır. $\mathrm{Bu}$ tür bilgileri benimsemek, eğitimcilerine, sınıfta kullanılabilecek çok çeşitli bilgiler ve potansiyel stratejiler sağlar. Eğitimciler için zorluk, tüm öğrencilerin nesiller boyu öğrenme stillerini iyi bir pedagoji ile dengelemektir ( Johnson \& Romanello, 2005: 216).

Otantik ve anlamlı deneyimler arayan Z Kuşağı, önceki kuşaklardan daha bağımsızdır - seçeneklerini araştırmak için çevrim içine dâhil olmak ya da iç görü için başkalarıyla etkileşime girmek- ancak nihayetinde ve önceki nesillerde olduğundan çok daha fazla kendi kararlarını almaktadırlar. Z Kuşağı, Milenyum Kuşağına göre daha pratik ve finansal güdümlüdür. Kendi kendine öğrenme tercihleri, kişisel tatmin ve sosyal etki konusunda bir merak ve endişeye neden olmaktadır.

Z Kuşağ 1 , özellikle kendilerini ilgilendiren kariyere erişim sağlaması ve finansal olarak ödüllendirilmesi anlamında yükseköğrenimin önemi ve değeri konusunda tutkulu görülmektedir. Onlar için okul iyi bir işe giden yol olarak görüldüğü söylenebilir. Doğal bağımsızlıklarına rağmen, büyük miktarda bilgiyi hılı bir şekilde işleyebilme yetenekleri, onları mükemmel öğrenciler olmaya doğru yöneltmektedir. Z Kuşağı'nda samimi bir öğrenme sevgisinin de güçlü şekilde mevcut olduğundan bahsedilebilir. Bu doğal özelliklerin onları üniversite kampüsüne götüreceğini, benzersiz

http://dergipark.gov.tr/aicusbed 5/2 Ekim / Oktober 2019 
olmaları ve bilgi arayışlarının hem eğitimciler hem de yöneticiler için yeni zorluklar ve firsatlar sunacağı tahmin edilmektedir.

Z Kuşağı'ndakilerin çoğunluğunun özel ilgi alanlarına uygun kariyer aramakta olduğundan ve bilgisayar bilimi, video oyunu geliştirme, yapay zekâ ürünleri ve geliştirilmesi gibi teknolojilerde kariyer geliştirmeleri öngörülmektedir. Bu gençlerin birçoğu, iş dünyasına girişimci olarak girmeye başladıklarından bahsedilebilir. $\mathrm{Bu}$ duruma Youtube kanalları vb. gösterilebilir. Özellikle 5-15 yaş arasındaki gençler diğer kuşaklarla karşılaştırıldığında şu anda kendi çevrim içi işlerine sahip olma ihtimallerinin iki kat fazla olduğu ifade edilebilir.

Z Kuşă̆ı'nın ilgi çekici, etkileşimli öğrenme deneyimleri istediği belirtilebilir. Meydan okumak istiyorlar, kendi kararlarını vermeleri için yetkilendirilmek istiyorlar ve dijital yerliler olarak teknolojinin eğitim deneyimlerinde önemli bir rol oynamasını bekliyorlar. Geleneksel ders kitaplarının kullanımının hâlâ yüksek olmasına rağmen, eğitim teknolojisinin ya da "ed tech"in geleceğinin şimdi olduğu inkâr edilemez bir gerçektir. Bu sebeple mevcut öğretmenlerin bu konuda kendini geliştirmesi ve ilgili kurumlarında Z Kuşağı'nın ihtiyaçlarına cevap verebilecek şekilde öz eleştiri yapmaları gerekmektedir.

Her ne kadar genç olsa da, Z Kuşağı'nın nedenler etrafinda mobilize olacağı ve önceki nesillerden daha sosyal ve çevresel olarak farkında olacağı görülüyor. En eski Z Kuşağı'nın (1995-2000 aras1 doğan) çoğu iş gücüne girmeye başlıyor ve tipik olarak teknoloji meraklısı; sosyal medya aracılığıyla akranlarına sosyal olarak bağli; parlak, önceki nesillerden daha yüksek IQ puanlarına sahip (Renfro, 2012). Z Kuşağı'nın kesintisiz bir arkadaş, veri ve eğlence dünyasına bağlı olduğu da söylenebilir. Okullarla ilgili olarak Renfro (2012), modern devlet okulu çağında (1920-gün) en çok okullu neslin bu nesil olduğunu ve $\mathrm{Z}$ Kuşağı'nın genellikle daha az yön gerektirdiğini ve bunları mümkün kılan dijital araçlara hazır erişimi olduğunu belirtmiştir. Bu sebeple bu kuşak özellikle güvenilir ve amaçlar doğrultusunda hazırlanmış yönlendiricilere gereksinim duymaktadır. Aksi durumda bilgi karmaşasında yolunu kaybetme olasıllğı yüksektir. Burada öğretmenlerin dijital göçebeler olarak dijital yerlilerin ihtiyaçlarını belirlemeleri ve bu doğrultuda öğretim yöntem ve stratejileri belirlemeleri önemlidir.

Renfro (2015), Z Kuşağı öğrencisinin grafik ve ders anlatımlarından hoşlanmadığını, anında geri bildirim beklediği ve özelleştirilmiş öğrenmeyi tercih ettiğini belirtmiştir. Çoğu durumda, Z Kuşağı öğrencilerinin öğretmenleri, öğrenciler kadar teknoloji konusunda rahat ve

http://dergipark.gov.tr/aicusbed 5/2 Ekim / Oktober 2019 
uzman değildir. Gelecekteki ihtiyaçları karşılamak için Z Kuşağı öğrencilerinin öğretmenleri tarafindan proje tabanlı aktif öğrenme fırsatları ile mücadele edilmesi gerekmektedir. Tipik olarak, Z Kuşağı öğrencileri, teknolojik olarak desteklenmiş öğrenme cihazlarında araştırdıklarının güvenilirliğini belirlemeye zaman ayırmaz. Bu nedenle, Z Kuşağı bireyleriyle çalışırken öğretmenler ve diğer liderler kaynakları değerlendirmelerine yardımcı olmaya odaklanmalıdır.

Renfro (2015), bugünün ilkokul öğrencilerinin \%65'inin şu anda mevcut olmayan işlerde çalışacağını belirtmiştir. Z Kuşağı'nın farklı tipte profesyonelliklere sahip olacağ söylenebilir haftada 40 saat çalışan çalışanlar değil, aynı zamanda belirli bir uzmanlık ile sorunları çözen büyük esnekliğe sahip serbest çalışanlar olarak düşünülebilecektir. Z Kuşağı, en büyük hizmet ekonomisinde olmasına rağmen, profesyonel ve teknik fikir ekonomisine girmek isteyecektir.

Diğer kuşakların üyeleri, Z Kuşağı'nın gelişen teknolojiler tarafindan yönlendirilen, değişen (veya eksik) sosyal becerilerini ele almalı ve bunlara uyum sağlamalıdır. Bugün öğretmenlerin neler öğrettiği ile geleceğin bilinmeyen ve ihtiyaç duyulan becerileri arasındaki boşluk genişlemektedir. Eğitimcilerin bilmesi gereken şey, Z Kuşağı'nın dünyasının giderek daha online olarak iş birlikçi olduğu, okul projelerinin ve eğitim ortamlarının bunu yansıtacak şekilde ayarlanması gerektiğidir. Özetle, öğretmenler için Z Kuşağı'nın öğrenenlerine, fikir ve bilgi çağında bu beceriler Z Kuşağı'na gerektiğinden, bilgileri keşfetmeyi, iyileştirmeyi ve yönetmeyi öğretmeleri önemlidir.

Z Kuşağı üyeleri teknoloji meraklısı olduğundan onları bu özellikleri ya da küresel akranları ve yaptıkları ile derslere bağlamanın mümkün olduğundan bahsedilebilir. Pasif TV ya da basılı metinler ve sinıf dersleri yerine medya ile etkileşimini tercih etmeleri sebebiyle özellikle öğrenme etkinliklerinde bu özellikleri göz önünde bulundurulmalıdır. Nerede ve ne zaman isterlerse çalışmayı ve öğrenmeyi ummalarından dolayı bu konu öğretmenlerce göz önünde bulundurulmalı ve bu konu ile ilgili gerek bireysel gerekse kurumsal bağlamda çalışmalar yapılmalıdır. Z Kuşağı üyelerinin yönlendirmeye daha az ihtiyacı vardır çünkü özellikle tutkulu oldukları durumlar için cevaplara erişebilirler ancak bu yönlendirme hem bilgi güvenirliği hem de doğru yönlendirme bakımından dikkat gerektiren bir süreçtir. Burada da eğiticilere önemli roller düşmektedir. Tutarlı ve çoklu görevli olarak görülen Z Kuşağı üyeleri sürekli geri bildirim, açık hedefler, ödüller ve kişisel zorluklar aramaktadırlar. Hızlı sonuç bekledikleri

http://dergipark.gov.tr/aicusbed 5/2 Ekim / Oktober 2019 
(promosyonlar) ve öz geçmişlerini kullanışlı ve güncel tutacakları için $Z$ Kuşağ1 üyeleri için esneklik önemlidir (Renfro, 2015). Z Kuşağı için diğer genel yaklaşımlar; azgelişmiş sosyal ve ilişki becerileri, zihinsel sağl1k kaygıları riskleri ile ilgilidir (Igel \& Urquhart, 2012; Seemiller \& Grace, 2016; Spears vd., 2015; Twenge, 2017; Wiedmer, 2015). Grup ve kişiler aras1 etkileşimlerin uygulayıcıları tarafından kolaylaştııılması gerekebilir. Aktif dinleme, yapıcı eleştiriler sağlama ve başkalarının bakış açılarına saygı duyma gibi uygun grup ve kişiler arası becerilerin açıklanması ve gösterilmesi, sosyal ve ilişki becerilerinin artırılmasına yardımcı olabilir. Eğitim verirken, bunu geliştirmek için kısa bir sosyal etkileşim patlamaları gerektiren etkinlikleri de dâhil etme düşünülmesi gereken bir konudur. Z Kuşağı'nda sağlığı teşvik eden davranışlarda bulunmaya teşvik edin. Bu nesil teknoloji baskınlığı sebebiyle duygusal ve belki de fiziksel sağlıklarına zarar verebilir (Igel \& Urquhart, 2012; Seemiller \& Grace, 2016; Spears vd., 2015; Twenge, 2017; Wiedmer, 2015). Kişisel bakım ve ekran süresini sınırlama stratejileri önerme (Twenge, 2017), Z Kuşağı'nın sağlık endişeleri riskine yardımcı olabilir. Gün içerisinde uygun ve yeterli teknoloji kullanımı hakkında rehberlik sağlamak da gerekli olabilir. Son olarak, öğrencilerle sosyal medya ile ilgili sınıf içi kararlar almak ve alınan sınıf içi kararları hatırlatmak, gizliliği ve mahremiyeti ihlal edebilecek ve tehlikeye atabilecek uygunsuz durumları engelleyecektir.

Lolarga (2016) Z Kuşağı'nın önceki nesillere göre çok daha erken büyüdüğünü ve daha pragmatik olduğunu ifade eder. $X \vee Y$ Kuşağ 1 ebeveynleri tarafından yetiştirilen Z Kuşağı üyeleri, genç yaşta kendi yollarını bulmak için çabalamaya teşvik edilmektedir. Onlar 18 yaşına kadar bu yetişkin dünyasına emsalsiz erişimleri ile bugün para ve akıllı satın alma alternatifleri konusunda kendi başlarına daha fazla karar vermişlerdir. Temelde 14-18 yaş arası gençlerin \%41'i kendilerini yetişkin olarak görmektedir. Bu zihniyetle, yetişkin davranışlarını denemek artık riskli veya cüretkâr değil, ortak ve pasif olarak görülmektedir. Dikkatlerini çekmek için onlarla akıllı yetişkinler olarak konuşmak gerekmektedir. Dijital tarafta, artık eski kardeşlerinden moda ipuçlarını almıyorlar, bunun yerine dünyanın her yerindeki blog ve YouTube kanallarındaki trend belirleyicilerden etkilenmektedirler. \%80'i, kendilerini yaratıcı bir şekilde ifade etmenin onlar için önemli olduğunu ve $\% 25$ oranında bir kısmı ise orijinal videoları en az haftada bir kez yayınlama ya da paylaşmanın çok mutlu ettiğini söylemektedir. $\mathrm{Bu}$ topluluğun \%90'ı günlük YouTube izlemekte, \%80'i günlük sosyal medya kullanmakta, \%70'i kablolu yayın üzerinden akışı takip etmeyi tercih etmektedir. Farklı bir sadakat beklentisiyle alışveriş yapmakta

http://dergipark.gov.tr/aicusbed 5/2 Ekim / Oktober 2019 
ve bu nedenle yeni şeyler denemekte, özellikle çevrim içi forumlardan görüş istemektedirler. Kendiliğinden yaşadıkları ve yetişkin oldukları zihniyetlerinin sizi kandırmasına izin vermeyin, sosyal değişimden etkilenirler ve ürünlerinin nereden geldiğine ve alımlarının fark yaratmasını isterler. Tanımlanan Z Kuşağı özelliklerini ve yetişkinlerin öğrenme ilkelerini göz önünde bulundurarak, geleneksel modellerin $Z$ Kuşağ 1 öğrencilerinin dikkatini çekmek için uygun olmadığı görülebilir. Bunun yerine, öğretmenlerin hayattaki gibi kapsamlı bir simülasyonla birleştirilen etkileşimli çevrim içi modüller gibi yenilikçi modelleri kullanabileceği ileri sürülebilir. Temel politikaları, prosedürleri, konuları, içerikleri ayrıntılarıyla açıklayan etkileşimli çevrim içi modülleri kullanmak, teknolojik açıdan eğimli, bireysel bir nesil olan $\mathrm{Z}$ Kuşağı öğrencisi için ilgi çekici olabilir. Yaşamın kapsamlı simülasyonunda günün uygulanması ve doğrulanması öğrenicilerin ilgisini çekecek, modül bilgilerinin ve gerekli yeterliliklerin ve becerilerin anlaşılmasını onaylayacaktır.

Öğretmenler Z Kuşağı'nın eğitiminde videolar, video paylaşım sitesi kanalları, oyunlar, kavram haritaları, sorgulama ve geri bildirim alıştırmaları ve infografikerlden (infographics) faydalanabilir. Bu hem bu neslin dikkatini çekecek hem de öğrenmesini kolaylaştıracaktır. Örneğin, bu infografik (infographic) sunumlar, görsel bir sunum yoluyla eleştirel öğrenme noktalarını vurgulayabilir ve böylece bu görsel öğrenenler için anlamada yardımcı olabilir. Teknoloji ile zenginleştirilmiş kısa grup temelli etkinlikler, gruplarını ve kişiler arası becerilerini geliştirirken Z Kuşağı'nı etkilemeye yardımcı olabilir. Akran koçluğu gibi teknolojiyle desteklenmiş kısa grup temelli etkinlikler, Z Kuşağı'nın aktifleşmesine ve gerekli kişiler arası becerilerin geliştirilmesine yardımcı olacaktır. Yetkinlik ve beceri doğrulaması için yaratıcı, kanıta dayalı yöntemler ayrıca Z Kuşağı'nın yönlendirilmesine, desteklenmesine ve geliştirilmesine de yardımcı olabilir. Sanal simülasyonlar, görev eğitmenleri ile standart hâle getirilmiş görevler, tartışmalar, örnekler gibi çeşitli teknolojilere dayalı kanıtlanmış yeterlilik ve beceri doğrulama yöntemleri ve rubrikler Z Kuşağı'nın grubunu ve kişiler arası becerilerini geliştirebilir, bağlantıyı artırabilir ve böylece kuşağının ruhsal ve fiziksel sağlık riskini azaltabilir. Teknoloji geliştirme, Z Kuşağı'nın aktifleşmesine yardımcı olur, yetkinlik ve becerilerin kazanılmasını sağlar. Örnek olarak öğretmenler, öğrencilerin diğer öğrencilere yardımcı olması ve öğrenmenin daha iyi hâle getirilmesi için sosyal medyayı veya diğer platformları kullanabilir. Teknolojiyle geliştirilmiş seçenekler, dikkat çekmeye ve Z Kuşağı öğrencilerinin ilgisini çekmeye yardımcı olacaktır.

http://dergipark.gov.tr/aicusbed 5/2 Ekim / Oktober 2019 
Öğrencilerin kanıta dayalı uygulama, araştırma ve/veya kalite geliştirme projeleri için kaynak elde ederken dijital kaynak güvenilirliğini, alaka düzeyini ve doğruluğunu belirleme konusunda derslere ihtiyaçları olabilir. Z Kuşağı'nı dinleyin, görüşlerini ve bakış açılarını göz önünde bulundurarak değerleyin (Seemiller \& Grace, 2016). Uygun olduğu üzere öğrencileri karar alma süreçlerine dâhil edin (Seemiller \& Grace, 2016). Bu, Z Kuşağı'na olan güveni artırmaya yardımcı olacaktır. Dürüst ve iletişimsel uygulayıcılar isteyecekleri için Z Kuşağ ile şeffaf olmak da önemlidir.

Swanzen (2018)'in Barnes, Marateo \& Ferris (2007); Shatto \& Erwin (2016)'dan uyarladığına göre Z Kuşağı'na yönelik öğretim ihtiyaçları şöyle belirlenmiştir;

\section{1- Öğretim Kuralları}

-Mümkün olduğunda mobil teknolojiyi ve uygulamaları kullanın. Tabletlerde veya akı1lı telefonlarda tamamlanabilecek okumaları kullanın.

-Facebook, Tumblr, Twitter, bloglar ve tartışma grupları gibi sosyal medya sitelerini kullanarak iş birliğini veya iş birlikli öğrenmeyi teşvik edin. Farklı bakış açılarına odaklanan grup çalışmasını kullanın.

-Öğrencilerin, hangi konu üzerinde çalıştıkları hakkında bir YouTube videosu bulmalarını veya yapmalarını sağlayın.

-Eleştirel düşünmeyi teşvik etmek için Jeopardy, Kahoot ve Socrative vb. gibi etkileşimli oyunlar kullanın.

-Laboratuar becerilerini sinıftaki, uygulamalara dâhil edin.

-Okumaları yalnızca gerekli bilgileri içerecek şekilde sınırlayın.

-Kapsayıcılık ve hoşgörü ile ilgili tartışmaları dâhil edin.

-Farklı geçmişlere sahip öğrencilere öğretirken anlatıları ve hikâye anlatıcılığını kullanın.

-Öğrencilerin web'den bilgi bulmalarına yardımcı olmak için WebQuest vb. gibi sorguya yönelik bir ders biçimi kullanın.

-Öğrencilerin ders notu ve materyal hazırlamalarının yanı sıra diğer öğrenciler için ders kitabı yazmalarını destekleyin.

\section{2- Öğretim İhtiyaçları}

-Öğrencilerin ihtiyaçlarına göre geri bildirim sağlayın.

-İş birlikçi öğrenmeyi teşvik edin.

-Döndürülmüşs sınıflar (flipped classroom) ve aktif öğrenme gibi yöntemler öğrencilerin aktif katılımını sağlar (örneğin, vaka çalışmaları, grup projeleri, oylama için tıklayıcıların kullanımı, bloglar ve eleştirel düşünme ödevleri) bunlar1 kullanın.

-YouTube videoları ile kavramları güçlendirin.

http://dergipark.gov.tr/aicusbed 5/2 Ekim / Oktober 2019 
-Eğlenceli ve modern bir şekilde öğrenme süreci yürütün.

-Araştırma için internet arama motorlarına ve videolara nasıl güvenebileceklerini öğretin.

-Gözlem ve deneyimsel uygulama ile daha fazla bilgi edinin.

-Öğretmenin daha fazla etkileşime girmesi ve daha az ders (öğüt anlamında) vermesi konusunu dikkate alın.

-Hemen cevap bekleyin ya da isteyin. Yaparak öğrenmek isteğini destekleyin. -Dijital bir dünyaya doğduklarından, kolayca erişilebilen bilgilerle nasıl başa çıkacaklarını ve bilgi karçaşasından nasıl kurutlacaklarını, bunun için hangi yolları kullanmaları gerektiğini öğretin.

Yukarıda ifade edilen maddeler daha etkili öğretim vermeye ve istendik davranışların istenen oranda ve yönde kazandırılmasında öğretmenlere yardımcı olabilecektir.

Z Kuşağı üyelerinin beceri ve görsel öğrenmesine fayda sağlamanın başka yolları da bilgi aktarabilen veya içeriğin uygulanmasına izin veren oyun etkinliklerinin kullanımını içerebilir. Beceri veya yeterliliklere ulaşıldığında lider panoları ve dijital rozetlerin kazanılması, bu öğrencilerin istediği ve ihtiyaç duyduğu sosyal yönü de artırabilir. Elektronik kitle müdahâle sistemleri katılımcıları problem çözmeye teşvik edebilir. Uygulayıcılara içerik değerlendirme, öğrenmeyi değerlendirme ve anında geri bildirim sağlama fırsatını sunabilir. Bunun yanı sıra uygulayıcıların Z Kuşağı'nın teknoloji doygunluğunu ve bugün mevcut olan bilgi miktarını da dikkate almaları gerekecektir (Di Leonardi, 2017; Igel \& Urquhart, 2012; Loveland, 2017; Rickes, 2016; Seemiller \& Grace, 2016; Shatto \& Erwin, 2016, 2017; Spears vd., 2015; Turner, 2015; Twenge, 2017; Wiedmer, 2015).

Elmore (2018)'in ebeveynlere önerdiği stratejileri öğretmenlik için de kullanmak mümkündür. Bunlara göre;

1. Çıldırmayın. Öncelik güvenlik olmakla birlikte, çocukların dünyadaki uygun riskleri almalarına izin vermeliyiz. Ancak, garip hatta çılgınca bir şey seçtiklerinde ya da yaptıklarında da sakin olunmalıdır. Ne yaparsanız yapın, gençlerin bugün vermekte güçlük çektikleri garip kararlardan -dövmelerden piercinglere, arkadaşlarla ilgili kararlara, cinsiyet akışkanlığına (cinsiyet yönünden ikiden fazla seçenekli ve gözler önünde olan, eskiden kabullenilmeyecek ilişkiler olarak ifade edebiliriz) - korkmayın. Çünkü bugünün çocukları çok yeni bir dünyada büyüyor ve yaşıyorlar. Duygusal olarak tepki göstermezsek ancak saygılı bir şekilde konuşursak, seçimlerinin uzun vadeli sonuçları üzerinden düşünmelerine yardımcı olma hakkını kazanırız. Bu bizim rolümüz: akıllı ve istikrarlı liderlik. Uzun vadeli

http://dergipark.gov.tr/aicusbed 5/2 Ekim / Oktober 2019 
düşünmeleri için onları donatın. Z Kuşağı'na büyük resmi görme ve yüksek düşünme becerisi kazandırılmaya çalışılmalıdır.

2. Onların doğru ve özel olduğunu onaylayın. Z Kuşağı çocukları, ebeveynlerinden gelen Milenyum Kuşağı hiperbolik övgülerine mahkûmdur. Onlar için her şey "harika" olarak- hatta olmadığında bile- tanımlandı. Yetişkin liderler, gençlere, gençlerin gerçek performansını yansıtan kelimelerle övgüde bulunmaları konusunda özendirmeli ve düşünceli olmalıdır. İstersek bize inanırlar. Ayrıca, kontrol edilemeyen şey yerine "kontrol edilebilir olan" çabayı onaylamalıyız.

3. Denklemleri konusunda net olun. Tonlarca kuralı olmaktan vazgeçerek sizi hayatın çocuklarının denklemlerini hatırlatmaya teşvik ediyoruz. Denklemler, bilge veya zayıf davranışların sonuçlarıdır. Eğer bunu yaparsanız, faydası budur; bunu yaparsanız, sonuç budur şeklinde düşünmelerine yardımcı olmak ve bu şekilde yol göstermek faydalı olacaktır. Sonuç olarak, öğrenciler yaşamın denklemlerle dolu olduğunu öğrenmeye başlar. Yetişkinliğe girdikten sonra günlük hayattaki ilişkileri ve denklemleri daha kolay yönetebilirler: kiranızı ödemezseniz dairenizi kaybedersiniz; zamanında kira ödüyorsanız sorun çıkmayacaktır vb. Bu tür denklemler, Z Kuşağı çocuklarını, dünyanın nasıl çalıştığı hakkında donatacaktır. Denklemleri netleştirin ve takip ettiğinizden emin olun.

4. Model tutarlılığı. Bugün dünyamızda dikkat çekici bir şekilde bulunmayan ögelerden biri tutarlılıktır. Tutarsızlık dışında hiçbir şey tutarlı görünmüyor. Belirsizlik her yerdedir. Değişim her zaman oluyor: boşanan çiftler, değişen işler, güncellenen işler, sonlandırılan TV şovları... Bu kuşağın en güvenilir bilgi kaynağı ya da olmazsa olmazı diyebileceğimiz internet bağlantısı bile sorunlu olabilir. Ebeveynler ve öğretmenler sözlü ve görsel ipuçlarında tutarlı olmalıdır. Tutarlı lider olarak gördükleri kişilerle birlikte çocuklar kendilerini güvende hissederler.

\section{Sonuç ve Öneriler}

Sonuç olarak Z Kuşağı'na daha etkili bir eğitim vermek için;

1- Öncelikle kurumların daha etkili ve yenilikçi bir yönlendirme ve yerleştirme yapması gerektiği söylenebilir. Ayrıca kurumlarca görevli eğitimi yeniden düşünülmeli ve tasarlanmalıdır. Kurumlarda basit değişiklikleri iletmek için infografik (infographic) hizmet içi el ilanları veya programları kullanılabilir. Öğretmenler ise öğrencilerini daha iyi tanımalı ve onları tanımak için gerekli adımları atmalıdır. Bu kapsamda öğrencilerin gelişim özelliklerini, yeteneklerini, kişisel özelliklerini bilmek önemlidir. Bu sebeple gerek okul rehber öğretmenlerine gerekse sınıf rehber öğretmenlerine önemli

http://dergipark.gov.tr/aicusbed 5/2 Ekim / Oktober 2019 
görevler düşmektedir. Bununla birlikte yetişkin toplum onlarla kendi dillerinde iletişim kurmayı ve anlayış göstermeyi öğrenecektir. Yaşamlarında kişisel verimlilik, iyi iletişim ve açik duygular, zorlu hayat yollarında kendi yollarını bulmak zorunda kalacakları için çok daha önemli bir rol oynamaktadır. Onları rehberlikle, tavsiyeyle değil, sorularına cevap bulmalarına yardımcı olacak sorularla, tartışmaya, birlikte düşünmeye teşvik edebiliriz. Onlarla kendi dillerinde konuşursak başaracağımıza eminiz (Tari, 2010: 1) Yerleşik öğretim modellerini, ölçme değerlendirmeyi ve bilgilerin yanı sıra öğretmen eğitimini yeniden değerlendirmek $Z$ Kuşağı'nın yönlendirilmesi, desteklenmesi ve geliştirilmesine yardımcı olacaktır.

2- Alaka düzeyi ve gerçek hayattan örnekler ile hayata yönelik oluşturulacak kapsamlı simülasyonlarda etkileşimli çevrim içi modüller kullanılabilir ve uygulayıcılar için Youtube vb. video paylaşım sitelerinde ya da kurum bünyesinde video kanalları oluşturulabilir.

3- Flipped (Ters döndürülmüş) sınıf modelleri ve açık, güvenli, destekleyici, saygılı ve iş birlikçi bir ortam geliştirmeyi içeren iletken bir öğrenme ortamı kullanılabilir.

4- Eğitsel programlar (Powtoon, Educreations vb.) yanında elektronik şablonlar ya da oyunlaştırma, kavram haritalama veya programları kullanarak zihin haritalama, elektronik izleyici yanıt sistemleri, emoji gibi uygulamalar ve platformlar aracılığıyla toplanan sorular ve geri bildirimler kullanılması, dijital rozet ve lider panoları dersin daha etkili ve eğlenceli geçmesine yardımcı olabilir.

5- Vaka senaryoları ve/veya video gibi teknolojiyle desteklenmiş vaka senaryolarının açılması, problem çözmenin video gibi teknolojilerle desteklenmesi fikirlerin toplanması ve ibeyinfirtınası (ibrianstorm), galeri yürüyüşü (gallery walking) ile fikirlerin ibrianstorm gibi bir (apps) uygulama ile toplanması, video gibi teknolojiyle desteklenmiş koçluk ve akran koçluğu uygulamaları yapılabilir.

6- Birkaç teknoloji platformuna sahip çoklu stratejiler, yaratıcı, kanıta dayalı ve çoğu zaman teknoloji ile geliştirilen yöntemle sürekli yetkinlik ve beceri doğrulaması geliştirme, sanal gerçeklik simülasyonları, rol oynama, elektronik eş yorumlar, sosyal medya veya diğer teknoloji platformlarını kullanarak tartışma ve yansıtma grupları, video, diyagramlar ya da infografikler gibi teknoloji destekli örnekler, elektronik rubrikler, kısa öğretme patlamaları (kısa sürede yoğun bilgi), kendi kendine yönlendirilen etkinlikler, iş birlikçi problem çözme kullanılabilir.

http://dergipark.gov.tr/aicusbed 5/2 Ekim / Oktober 2019 
34|A rş. Gör. A h m et $\mathrm{Kar}$ a do ğa

7- Oynadıkları oyunlar vb. sebeplerle Z Kuşağı'nın el göz ve kulak koordinasyonu gelişmiştir. $\mathrm{Bu}$ sebeple çoklu görevler verilebilir ve bu görevlerin etkili kullanım ile bu beceriler geliştirilebilir. Ayrıca bu topluluğun sosyal medya, oyun üretme, programlama, program yazma, Youtuberlık vb. çevrim içi meslekleri de olabileceğinden özellikle kurumlar ve öğretmenler tarafindan çok yönlü kariyer gelişimi de desteklenmelidir.

Daha önceki nesiller hakkında derinlemesine bir araştırma yapılması ve daha sonra farklı nesiller arasında net bir ayrım gösterebilecek daha geçerli cevaplar alabilmek için (Desai \& Lele, 2017) daha derinlemesine araştırmalar yapılmalıdır. 1995'in başlarında doğmuş olan Z Kuşağı'nın en eski üyeleri yeni yeni iş hayatına başlamakla birlikte büyük bir çoğunluğu hâlâ ilköğretim, lise ve üniversitelerde öğrenim görmektedir. Bu sebeple öğretimin daha etkili olması, bu kuşağın daha iyi bireyler ve meslek sahipleri olabilmesi için özellikle öne çıkan özellikleri ele alınmalı ve öğretim programları da bu yönde şekillenmelidir. Öğretmen yetiştiren kurumlar bu doğrultuda yeni nesil öğretmenler yetiştirmekle birlikte okulların revizyondan geçirilmesi de öngörülebilir. Z Kuşağı üyeleri iş gücüne girmeye devam ettikçe yeni yaklaşımları ve öğretme-öğrenme uygulamalarının gerekeceği söylenebilir. $\mathrm{Bu}$ sebeple öğretmenlerin bu değişiklikleri kolaylaştırabilen ve başarı sağlayabilen yetkinlikte olması hayati öneme sahiptir. Öğretmenlerin geri bildirim ve şeffaflık sağladıkları besleyici, güven verici ortamlar sağlaması ve Z Kuşağı üyelerini dinlemesi, dikkate alması ve değer vermesi gerekir. Sosyal davranış ve ilişki becerileri ile sağlıklı davranışların teşvik edilmesi ve kolaylaştırılması tavsiye edilebilir. Öğretme-öğrenme uygulamaları da, Z Kuşağı'nın etkin bir şekilde yönlendirilmesi, desteklenmesi ve geliştirilmesi için yeniden tasarlanmalıdır. Teknolojik ve aktif öğrenme ilkelerini kullanarak uygulanan oryantasyon modelleri, personel eğitimi, yetkinlik ve becerilerini yeniden tasarlamak, Z Kuşağı'na ulaşmaya yardımcı olacaktır. Bilgi okuryazarlığı öğretimi yoluyla yapılan sorgulama bu dijital olarak yerli nesil için de hayati öneme sahiptir. Bu nesille ilgili veriler her ne kadar yeni ortaya çıksa da, iş gücüne yeni başladığı için, Z Kuşă̆ı'nın etkilerini ve özelliklerini tartışıp buna göre yol haritası çizmek, öğretmenlerin karmaşık rollerini yerine getirmelerine yardımcı olabilir. Bu nesli başarıyla yönlendirmek, desteklemek ve geliştirmek bireyleri, kuruluşları ve nihayetinde ülkeyi olumlu yönde etkileyecektir.

http://dergipark.gov.tr/aicusbed 5/2 Ekim/ Oktober 2019 


\section{Kaynakça}

Andrea, B., Gabriella, H. C., \& Tímea, J. (2016). Y and Z Generations at Workplaces. Journal of Competitiveness, 8(3), pp.90-106.

Bassiouni, D. H., \& Hackley, C. (2014). 'Generation Z' children's adaptation to digital consumer culture: A critical literature review. Journal of Customer Behaviour, 13(2), 113e133.

Bencsik, A., \& Machova, R. (2016). Knowledge sharing problems from the viewpoint of intergeneration management. In ICMLG2016-4th International Conference on Management, Leadership and Governance: ICMLG2016 (pp. 42-50). St Petersburg, Russia: Academic Conferences and Publishing Limited.

Bump, P. (2015). Your generational identity is a lie. https://www.washingtonpost.com/news/thefix/wp/2015/04/01/yourgenerational-identity-is-alie/?noredirect=on\&utm:term $=.03$ ecdbe $37 \mathrm{f} 97$ adresinden erişilmiş̧ir.

Chicca, J., \& Shellenbarger, T. (2018). Generation Z: Approaches and Teaching-Learning Practices for Nursing Professional Development Practitioners. Journal for nurses in professional development, 34(5), 250-256.

Childs, R., Gingrich, G., \& Piller, M. (2009). The future workforce: Gen Y has arrived. Engineering Management Review, 38(3), 32-34.

Coates, J. (2007). Generational learning styles. River Falls, WI: LERN Books

Cross-Bystrum, A. (2010, August 20). What you need to know about Generation Z. iMedia Connection. Erişim adresi: http://www.imediaconnection.com/content/27425.asp\#multiview

Desai, S. P., \& Lele, V. (2017). Correlating internet, social networks and workplace- a case of generation Z students. Journal of Commerce \& Management Thought, 8(4), 802-815. doi:10.5958/ 0976478X.2017.00050.7

Dulin, L. (2005). Leadership preferences of a Generation Y cohort: A mixed methods investigation. Ph.D. dissertation, University of North Texas, United States -- Texas. Retrieved from ABI/INFORM Global. (Publication No. AAT 3181040).

Elmore, T. (2018). Four Parenting Strategies for Leading Generation Z https://growingleaders.com/blog/four-parenting-strategies-forleading-generation-z/_08.05.2019 adresinden erişilmiştir.

http://dergipark.gov.tr/aicusbed 5/2 Ekim / Oktober 2019 
Elmore, T. (2019a). Three Statistics that Will Change the Way You Think about Generation $\mathrm{Z}$ https://growingleaders.com/blog/threestatistics-that-will-change-the-way-you-think-about-generation-z/ adresinden 08.05.2019 tarihinde erişilmiştir.

Elmore, T. (2019b). How Generation Z is Changing the World of Dating https://growingleaders.com/blog/how-generation-z-is-changingthe-world-of-dating/ adresinden 08.05.2019 tarihinde erişilmiştir.

Elmore, T. (2019c). Six Defining Characteristics of Generation Z https://growingleaders.com/blog/six-defining-characteristics-ofgeneration-z/ adresinden 08.05.2019 tarihinde erişilmiştir.

Eskicumalı, A. (2002). Öğretmenlik Mesleğine Giriş içinde Eğitim, Öğretim ve Öğretmenlik Mesleği (Edt. Yüksel Özden). Pegema Yayıncılık. Ankara

Fry, R. (2016). Millennials overtake Baby Boomers as America's largest generation. Erişim adresi: http://www.pewresearch.org/facttank/2016/04/25/millennials-overtake-baby-boomers/

Glum, J. (2015). Marketing to Generation Z: Millennials move aside as brands shift focus to under-18 customers. International Business Times.

Göçer, A. (2018). Temel Dil Becerilerinin Birbirleriyle İlişkisi ve Bireyin Anlam Evreninin Oluşumu ve Gerçek Yaşam Becerileri Açısından Önemi. Eğitim ve Öğretim Araştırmaları Dergisi Journal of Research in Education and Teaching. Kasım 2018 Cilt: 7 Sayı: 4

Günüç, S. (2011). Dijital Yerlilerde Çalışan Bellek ve Çoklu Görev. 5. Uluslararas1 Bilgisayar ve Öğretim Teknolojileri Sempozyumu, 2224 Eylül, Frrat Üniversitesi.

Horovitz, B. (2012, May 4). After Gen X, Millennials, what should next generation be? USA Today Money. http://usatoday30.usatoday.com/money/advertising/story/2012-0503/naming-the-next-generation/54737518/1 adresinden 03.02. 2019 tarihinde erişilmiştir.

Howe, N. \& Strauss B. (1993). 13th Gen: Abort, Retry, Ignore, Fail? New York: Vintage Books.

Howe, N. \& Strauss, W. (2000). Millennials Rising: The Next Great Generation. New York: Vintage Books.

Howe, N., \& Strauss, W. (2003). Characteristics of the Millennial Generation. https://students.rice.edu/images/students/AADV/Oweek2008AAD VResources/Characteristics\%20of\%20the\%20Millenial\%20Genera tion.pdf adresinden erişilmiştir. 
Howe, N. \& Strauss, W. (2007). The Next 20 Years: How Customer and Workforce Attitudes Will Evolve. Harvard Business Review, 85 (78): 41-52.

Howe, N. \& Strauss, W. (2007a). Helicopter Parents in The Workplace, http://www.wikinomics.com/blog/uploads/helicopter-parents-inthe-workplace.pdf adresinden erişilmiştir.

Howe, N. (2014a). Introducing the Homeland Generation (Part 1). https://www.forbes.com/sites/neilhowe/2014/10/27/introducingthe-homeland-generation-part-1-of-2/\#7bce43102bd6 adresinden erişilmiştir.

Howe, N. (2014b). Introducing the Homeland Generation (Part 2). https://www.forbes.com/sites/neilhowe/2014/10/31/introducingthe-homeland-generation-part-2-of-2/\#1d6cfcbccbb6 adresinden erişilmiştir.

Isacosta (ууу. List of generations chart. http://www.hbcukidz.co/uploads/8/2/0/0/8200815/generations_cha rt.pdf adresinden erişilmiştir.

Igel, C., \& Urquhart, V. (2012). Generation Z, meet cooperative learning. Middle School Journal, 43(4), 16Y21.

Jenkins, R. (30 Temmuz 2017). Who are the generations? [Video dosyas1]. https://www.youtube.com/watch?v=IYOeDIOxKjc adresinden erişilmiştir.

Johnson, S. A., \& Romanello, M. L. (2005). Generational diversity: teaching and learning approaches. Nurse educator, 30(5), 212-216.

Jonas-Dwyer, D., \& Pospisil, R. (2004). The Millennial effect: Implications for academic development. Research and Development in Higher Education: Transforming Knowledge into Wisdom, 27, 194-206. http://www.herdsa.org.au/publications/conference proceedings/research-and-development-higher-educationtransforming-18 adresinden erişilmiştir.

Karabulut, B. (2015). Bilgi Toplumu Çağında Dijital Yerliler, Göçmenler ve Melezler. Pamukkale Üniversitesi Sosyal Bilimler Enstitüsü Dergisi, 21.

Lenhart, A. (2013). Teens, social media, and privacy: Reputation management, third party access, \& exposure to advertising. Presentation to the State of Maryland's Children Online Privacy Working Group at the Attorney General's Office in Baltimore. PewResearch Internet Project. 
Lolarga, J. (1 Mart 2016). Millennials vs Gen Z: Understanding generational preferences \& their motivations [Blog yazıs1]. https://www.linkedin.com/pulse/millennials-vs-gen-zunderstanding-generational-jacob-lolarga adresinden erişilmiştir.

Loveland, E. (2017). Instant generation. The Journal of College Admission, $235,34 Y 38$.

Marshâll, G. (1999). Sosyoloji Sözlüğü. (çev. Osman Akınhay, Derya Kömürcü). Bilim ve Sanat Yayınları Ankara

Martin, C. A. \& Tulgan, B. (2002). Managing the Generational Mix. Amherst, MA: HRD Press.

Matthews, V. (2008). Generation Z: New kids on the virtual block [Blog yazis1]. http://www.personneltoday.com/hr/generation-z-new-kidson-the-virtual-block/ adresinden erişilmiştir.

MEB. (2017). Öğretmenlik Mesleği Genel Yeterlikleri. Ankara

Menzies, D. (уyy.). Generation Z: The digital natives. The Official Home of Dave Menzies. http://davemenzies.com/digital-marketing2/generation-z-digital-natives/ adresinden erişilmiştir.

Mutte, J-L. (2004). Managing workers of the next decade. http://www.expatica.com/hr/story/managing-workers-of-thenextdecade-11866.html?ppager=1 adresinden erişilmiştir.

Palfrey, J. \& Gasser, U. (2008). Born digital: Understanding the first generation of digital natives. Basic Books, New York

Philip, T. M., \& Garcia, A. D. (2013). The importance of still teaching the iGeneration: Newtechnologies and the centrality of pedagogy.

Prensky, M. (2001a). Digital Natives, Digital Immigrants Part I. NCB University Press, 9 (5).

Prensky, M. (2001b). Digital Natives, Digital Immigrants, Part II: Do They Really Think Differently?. NCB University Press, 9 (6).

Prensky, M. (2004). The Emerging Online Life of the Digital Native: What they do differently because of technology, and how they do it. http://www.marcprensky.com internet adresinden 02.04.2019 tarihinde elde edilmiştir.

Puiu, S. (2016). Generation Z- A new type of consumers. Young Economists Journal, 13(27), 67-78.

Reeves, T. C., \& Oh, E., (2008). Generational differences. Handbook of research on educational communications and technology, 3, 295303. 
Relander, B. (2014). How to market to Gen Z, the kids who already have $\$ 44$ billion to spend. Entrepreneur Media.

Renfro, A. (2012). December 5). Meet Generation Z. Getting Smart. http://gettingsmart.com/2012/12/meet-generation-z/ adresinden erişilmiştir.

Rickes, P. S. (2016). Generation in flux: How Gen Z will continue to transformhigher education space. Planning for Higher Education Journal, 44(4), 21 Y45.

Robertson Associates. (2013). Which generation are you? X/Y/Z? Lost? http://www.robertsonassociates.eu/blog/2013/11/29/whichgeneration-are-you-xyz-lost adresinden erişilmiştir.

Seemiller, C., \& Grace, M. (2016). Generation Z goes to college. San Francisco, CA: Jossey-Bass.

Schlossberg, M. (2016). Teen Generation $\mathrm{Z}$ is being called 'millennials on steroids,' and that could be terrifying for retailers. Retrieved 9, 2016, from Business Insider UK http://uk.businessinsider.com/millennials-vs-gen-z-2016-2 adresinden erişilmiştir.

Schroer, W. J. (2008). Generations X, Y, Z and the others. The Portal, 40, 9. http://iam.files.cmsplus.com/newimages/portalpdfs/2008_03_04.pdf____adresinden erişilmiştir.

Shafrir, D. (2011). Generation Catalano: We're not Gen X. We're not Millennials [Blog yazis1]. http://www.slate.com/articles/life/culturebox/2011/10/generation_c atalano_the_generation_stuck_between_gen_x_and_the_m.html adresinden erişilmiştir.

Shatto, B., \& Erwin, K. (2016). Moving on from Millennials: Preparing for Generation Z. The Journal of Continuing Education in Nursing, 47(6), 253Y254. doi:10.3928/00220124-20160518-05

Shatto, B., \& Erwin, K. (2017). Teaching Millennials andGeneration Z: Bridging the generational divide. Creative Nursing, 23(1), $24 Y 28$. doi:10.1891/1078-4535.23.1.24

Shih, W., \& Allen, M. (2007). Working with Generation-D: Adopting and adapting to cultural learning and change. Library Management, 28(1/2), 89-100.

Sönmez, V. (2008). Program Geliştirmede Öğretmen El Kitabı. Anı Yayıncılık. Ankara 
Spears, J., Zobac, S. R., Spillane, A., \& Thomas, S. (2015). Marketing learning communities to Generation $\mathrm{Z}$ : The importance of facetoface interaction in a digitally driven world. Learning Communities Research and Practice, 3(1), 1 Y10.

Stankorb, S., \& Oelbaum, J. (2014). Reasonable people disagree about the post-Gen $\quad \mathrm{X}, \quad$ pre-Millennial generation. https://www.good.is/articles/generation-xennials adresinden erişilmiştir.

Sterbenz, C. (2015). Here's who comes after Generation Z - and they'll be the most transformative age group ever. http://www.businessinsider.com/generation-alpha-2014-7-2 adresinden erişilmiştir.

Strauss W, Howe N. (1991). Generations: The History of America's Future, 1584-2069. New York: Quill; 1991.

Strauss, W. \& Howe, N. (1991). Generation Z. http://www.teendisciples.org/generation-z.docx adresinden 09.04.2019 tarihinde edinilmiştir.

Swanzen, R. (2018). Facing the generation chasm: The parenting and teaching of Generations $\mathrm{Y}$ and Z. International Journal of Child, Youth and Family Studies, 9(2), 125-150.

Şahin, M. Can (2009). Yeni Binyılın Öğrencileri’nin Özellikleri. Anadolu Üniversitesi Sosyal Bilimler Dergisi, 9 (2).

Şenbir, H. (2004). Z "Son insan” mı? Z kuşağı ve sonrasına dair düşünceler. Okuyan Us Yayın.

Tabscott, J. (2009). Grown up digital: how the net generation is changing your world. New York, McGraw-Hill Professional.

Tari, A. (2010). Az $\mathrm{Y}$ és mögötte a $\mathrm{Z}$ generáció. http://www.budapestedu.hu/data/cms47443/okopannon_tari.pdf adresinden erişilmiştir.

Tari, A. (2011). Z generáció. Budapest: Tericum Kiadó Kft.

Tonta, Y. (2009). Dijital Yerliler, Sosyal Ağlar ve Kütüphanelerin Geleceği. Türk Kütüphaneciliği, 23 (4).

Turner, A. (2015). Generation Z: Technology and social interest. The Journal of Individual Psychology, 71(2), 103-113.

Twenge, J. M. (2017). iGen: Why today's super-connected kids are growing up less rebellious, more tolerant, less happy- and completely unprepared for adulthood and what that means for the rest of us. New York, NY: Atria Books.

http://dergipark.gov.tr/aicusbed 5/2 Ekim / Oktober 2019 
Veen, W. (2007). Homo Zappiens and the Need for New Education Systems. https://www.oecd.org/edu/ceri/38360892.pdf internet adresinden 05.03.2019 tarihinde erişilmiştir.

Wiedmer, T. (2015). Generations do differ: Best practices in leading traditionalists, boomers, and generations X, Y, and Z. Delta Kappa Gamma Bulletin, 82(1), 51.

Yaşaroğlu, C . (2018). Öğretmenlik Mesleğinin Geleceği Üzerine Bir Öngörü Denemesi. Akademik Matbuat, 2 (1), 16-29. http://dergipark.org.tr/matbuat/issue/38355/382136

Zeigenhorn, T. L. (2017). There's now a name for the micro generation born between 1977-1983. Did you know? [Blog yazis1]. https://didyouknowfacts.com/theres-now-a-name-for-the-microgeneration-born-between-1977-1983/ adresinden erişilmiştir.

Zemke, R., Raines, C., \& Filipczak, B. (1999). Generations at work: Managing the clash of Veterans, Boomers, Xers, and Nexters in your workplace. Amacom. 

